\title{
Actors Excluded from the Business
}

Ordinary Logics of Professional Disqualification and Degradation in Artistic Practice

Des comédiens exclus du métier. Logiques ordinaires de disqualification professionnelle et d'altération de l'activité artistique

Actores excluidos del oficio. Lógicas ordinarias de descalificación profesional y de variación de la actividad artística

\section{Serge Katz}

Translator. Alba Simaku

\section{(2) OpenEdition}

\section{Journals}

Electronic version

URL: http://journals.openedition.org/bssg/91

DOI: $10.4000 /$ bssg. 91

ISSN: 2490-9424

\section{Publisher}

Presses universitaires de Vincennes

\section{Electronic reference}

Serge Katz, "Actors Excluded from the Business", Biens Symboliques / Symbolic Goods [Online], 1 | 2017, Online since 15 October 2017, connection on 04 March 2021. URL: http://journals.openedition.org/ bssg/91; DOI: https://doi.org/10.4000/bssg.91 

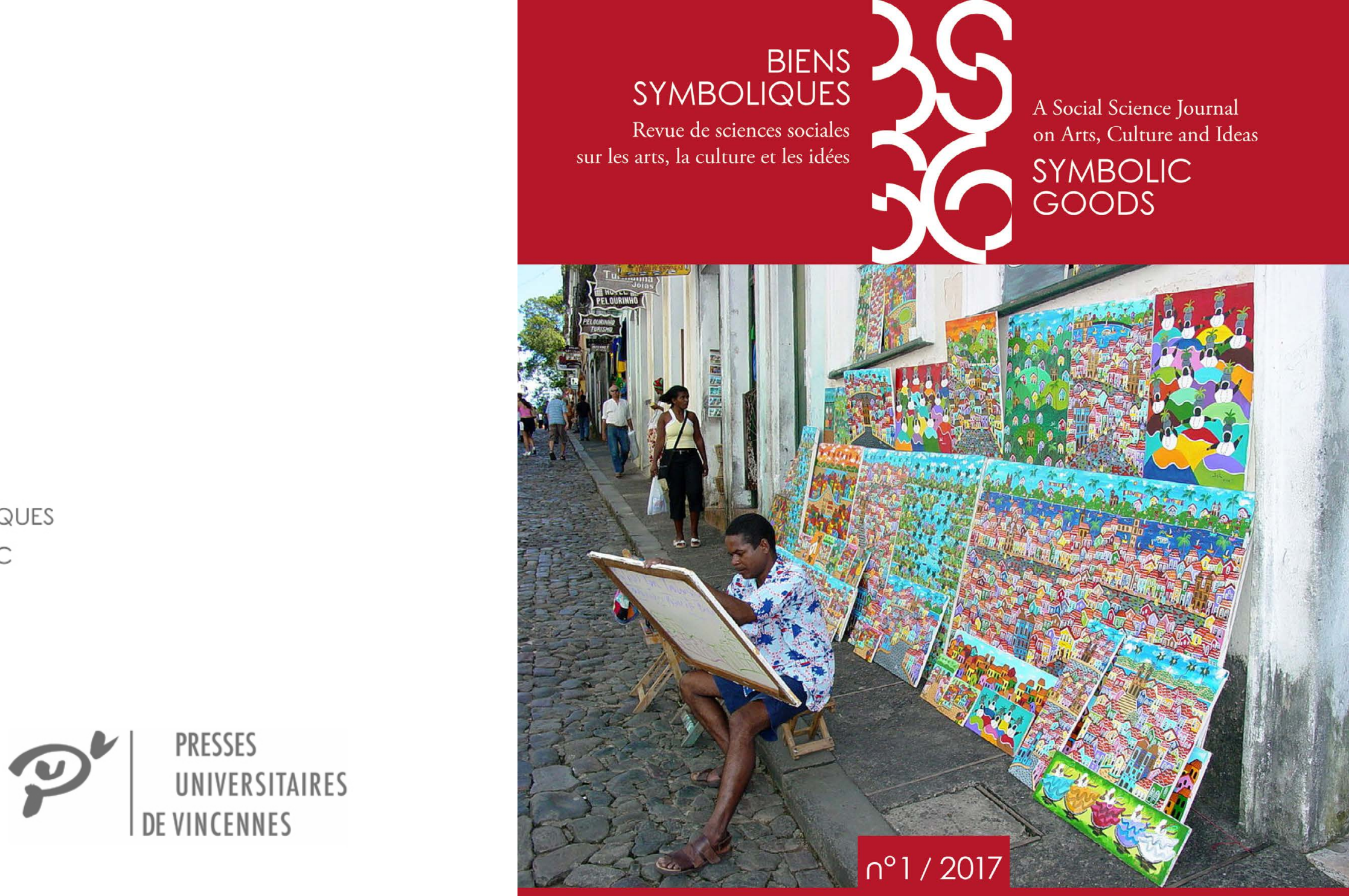

\section{Artistes ordinaires \\ Ordinary Artists}


Des comédiens exclus du métier

Logiques ordinaires de disqualification professionnelle et d'altération de l'activité artistique
Actors Excluded from the Business Ordinary Logics of Professional Disqualification and Degradation in Artistic Practice

Serge Katz

traduction | translation

Alba Simaku

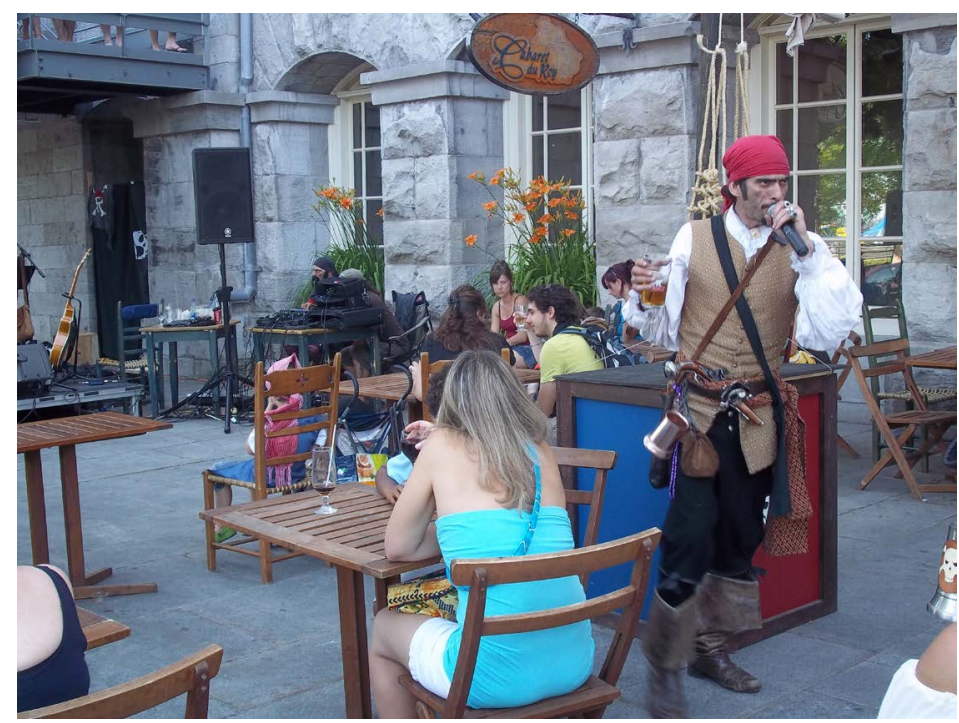

Des comédiens serveurs et animateurs

Actors waiting tables and leading groups

Source : https://commons.wikimedia.org/w/index

php?title=Special $:$ Search $\&$ limit $=20 \&$ offset $=20 \&$ profile $=$ default $\&$ search $=$ 
Dans une volonté de rompre avec les discours dominants sur l'art, la plupart du temps préoccupés par les grands maîtres et les génies, la sociologie des activités artistiques a beaucoup puisé dans le répertoire méthodologique et théorique de la sociologie interactionniste américaine. Celle-ci, qui s'était elle-même construite contre l'apologie - portée par les auteurs fonctionnalistes - du rôle social des professions les plus prestigieuses, a grandement incité les chercheurs à tourner leur attention vers les « petits métiers ", voire les activités socialement dépréciées ou stigmatisées (Demazière \& Gadéa 2009 ; Champy 2009). À l'instar d'Howard Becker prenant pour objet la carrière des « musiciens de danse » (Becker 1985), nombreux sont aujourd'hui les chercheurs qui, étudiant diverses professions artistiques, ont contribué à la désacralisation des « mondes de l'art » en décrivant les tâches les plus prosaïques et les positions les plus ordinaires ${ }^{1}$.

Dès lors que l'on s'intéresse au métier de comédien, détourner le regard des stars et des vedettes impose d'observer les espaces sociaux appropriés : comment être sûr d'atteindre " les degrés inférieurs de la pyramide professionnelle » où les artistes « ordinaires » seraient amenés à évoluer (Perrenoud 2013 : 86) ? La multi-activité des comédiens nécessite de les suivre dans des organisations très diverses et des secteurs artistiques hétérogènes. Elle exige de prendre en compte une pluralité d'univers professionnels, aux critères concurrents de consécration. En outre, porter l'attention vers

1 Je remercie Géraldine Bois et Marc Perrenoud, ainsi que les rapporteurs anonymes de la revue pour leur relecture attentive. Les erreurs et imperfections qui pourraient subsister sont, bien entendu, miennes.
The sociology of artistic practice has heavily drawn onAmerican interactionist sociological theories and methodologies, in a desire to break with the dominant discourse on art that is too often focused exclusively on the great masters and geniuses. Interactionist sociology was itself conceived against the usual praise of the social role of more prestigious professions by functionalist authors, and greatly encouraged researchers to turn their attention to "smaller occupations," or even socially devalued or stigmatized activities (Demazière \& Gadéa 2009; Champy 2009). Following Howard Becker's example of the careers of "dance musicians" as his chosen object (Becker 1985), many researchers, having studied various artistic professions, have contributed to the desecration of "art worlds" by describing the most mundane tasks and common positions ${ }^{1}$.

A sociological interest in the acting profession which turns away from celebrity and stardom requires an observation of the appropriate social spaces: how can we be sure of reaching "the lower levels of the professional pyramid," where "ordinary" artists are forced to evolve? (Perrenoud 2013: 86). The various activities of actors need to be examined within highly diverse organisations and heterogeneous artistic sectors. This requires considering the plurality of the professional sphere and the competitive criteria of recognition. Furthermore, paying attention to the "lower" spheres requires some knowledge

I would like to thank Géraldine Bois and Marc Perrenoud, as well as the anonymous reviewers for their careful reading of my text. Any errors and imperfections that may remain are of course my own. 
le « bas » suppose de saisir comment se construit la frontière inférieure, qui sépare les artistes professionnels, fussent-ils voués à l'anonymat, des profanes. Si l'on reconnaît là un des défis classiques lancés à la sociologie de l'art, en particulier concernant la différenciation entre professionnel et amateur (Freidson 1986 ; Weber \& Lamy 1999), la question se pose de façon singulière pour les comédiens en France. Ceuxci sont en effet des intermittents du spectacle : tout comme les autres artistes et techniciens salariés du spectacle vivant ou enregistré, ils évoluent sur un marché du travail « hyperflexible », régi par l'usage étendu de contrats de très courte durée ajustés à l'organisation par projet de l'activité ; cette exception est redoublée par une deuxième : afin d'assurer la discontinuité de leur emploi, les règles d'accès à l'indemnisation chômage leur sont beaucoup plus favorables qu'aux salariés des autres branches (Menger 2011). Dans les faits, l'indemnisation chômage est largement devenue un revenu de complément, voire un revenu principal (Cardon 2011 ; Gille 2013), à tel point que l'éligibilité à ces droits, ouverte au terme minimum de 507 heures travaillées en 10 mois et demi ${ }^{2}$, est couramment envisagée comme un « statut » qui distinguerait le professionnel du travailleur occasionnel (Menger 1997 ; Sinigaglia 2012 ; Langeard 2013).

2 Ces critères, qui s'appliquent aux artistes (la période de cotisation étant de 10 mois pour les techniciens), sont valables depuis la réforme de $2003 \mathrm{de}$ l'indemnisation chômage des intermittents du spectacle. L'accord trouvé le 28 avril 2016 entre organisations syndicales de salariés et d'employeurs du secteur du spectacle doit déboucher sur la restauration du cadre annuel de cotisation et allocation antérieurs à partir du $1^{\text {er }}$ août 2016. about how the boundaries that differentiate professional artists from laymen-however anonymous the former-are constructed. This is one of the classic challenges aimed at the sociology of art, specifically concerning the difference between professional and amateur situations (Freidson 1986; Weber \& Lamy 1999). But the question is posed somewhat differently for actors in France, who are indeed employed as intermittents du spectacle (entertainment industry contract workers). Like other live or recorded artist employees and show technicians, they operate within a "hyper-flexible" employment market governed by the extensive use of very short-term contracts characteristic of project-based activities. This exception is followed by another: to insure against the discontinuity of their employment, access to unemployment benefits for these individuals operates in their favour, in comparison with workers from other industries (Menger 2011 [2005]). In fact, unemployment benefits have generally become an income supplement, or even a main income (Cardon 2011; Gille 2013) to the point that eligibility for these rights (available for a minimum of 507 hours worked in ten and a half months ${ }^{2}$ ) is commonly considered to be a "status" that distinguishes occasional artists from "professionals" (Menger 1997; Sinigaglia 2012; Langeard 2013).

2 These criteria apply to artists (the assessment period for technicians is ten months), and have been valid since the 2003 unemployment insurance reform to intermittent performer status. The agreement reached on $28 \mathrm{Apri}$ 2016 between trade unions and employers in the entertainment industry resulted in restoration of the annual assessment and previous benefits framework from 1 August 2016. 
C'est cette configuration paradoxale de la qualification par la situation de non-emploi que l'enquête présentée ici aborde, en étudiant les trajectoires d'individus qui ont initialement connu une intégration professionnelle, marquée par l'accès régulier à l'assurance chômage, puis une perte prolongée, voire définitive, de ces mêmes droits ${ }^{3}$. Ce faisant, c'est bien à une population de comédiens « ordinaires ${ }^{4}$ » que l'on s'est intéressé ici, à savoir des artistes ni riches, ni célèbres, ni consacrés par les espaces de production restreinte du cinéma ou par le jugement des pairs au théâtre. Pour autant, ces artistes ont connu une trajectoire protéiforme : non seulement en passant d'une stabilité professionnelle momentanée à une baisse décisive de leur activité, mais encore, du fait de la plasticité qui caractérise le marché du travail de comédien, en alternant emplois relativement valorisés et positions plus dépréciées et marginales. De ce fait, leurs trajectoires ont agi comme un révélateur des principes de (dis-)qualification à l'œuvre sur ce marché. Leurs expériences sont en effet

3 Outre des matériaux issus de recherches précédentes sur la professionnalisation et le marché du travail de comédien, l'enquête a mobilisé une quarantaine d'entretiens réalisés entre janvier 2012 et juin 2013 : 28 avec des comédiens exclus de l'indemnisation chômage (intégrés plus de trois années, exclus au moins quatre mois consécutifs - voir en annexe les caractéristiques des comédiens interrogés), et 14 entretiens avec des intermédiaires professionnels. Sur les caractéristiques sociales des enquêtés, voir l'encadré. L'enquête s'appuie par ailleurs sur les données quantitatives fournies par Audiens, groupe de protection sociale des secteurs de la culture, de la communication et des médias. Elle a été soutenue par I'Union des Artistes et le Fonds de professionnalisation et de solidarité des artistes et techniciens du spectacle. Elle a donné lieu à la publication d'un livre (Katz 2015).

4 J'emprunte le terme et sa définition à Marc Perrenoud (2007) et Jérémy Sinigaglia (2013), en l'adaptant au métier de comédien.
This paradoxical configuration which qualifies the unemployment situation is addressed here, by studying the trajectories of individuals who have initially enjoyed a certain amount of professional integration with regular access to unemployment insurance, but who have been affected by the prolonged, even definitive, loss of these rights ${ }^{3}$. In doing so, we are interested here in the group of "ordinary" namely those who are neither rich nor famous, nor involved in the limited spaces of cinema production or peer judgement in theatre. However, these artists have experienced a protean trajectory: not only from momentary job stability to a significant decline in their activity, but furthermore owing to the plasticity of the acting field, alternating relatively respected jobs with less prestigious and marginal positions. As a result, their trajectories have revealed the (dis)qualification factors at work in this domain. Their experiences are indeed widely representative not only of the central position that theatre employment holds in enabling actors to maintain a stable

3 In addition to previous research on professionalization in the acting business, around forty interviews were held in this survey between January 2012 and June 2013: twenty-eight of these were conducted with actors who were excluded from unemployment benefits (having been entitled to them for more than three years, excluded for at least four consecutive months - see section on the characteristics of the interviewed actors), as well as interviews with professional intermediaries (fourteen). The survey is also based on quantitative data provided by Audiens, a social welfare group for employees in the cultural sector, communications, and the media. It was supported by the Union des Artistes and the Fonds de professionnalisation et de solidarite des artistes et techniciens du spectacle (a solidarity fund for entertainment artists and technicians). This gave rise to the publication of a book (Katz 2015).

4 I borrow this term and its definition from Marc Perrenoud (2007) and Jérémy Sinigaglia (2013) and adapt it to the acting profession. 
largement représentatives non seulement de la place centrale qu'occupel'emploi théâtral dans la stabilisation professionnelle des comédiens, mais aussi, au sein de ce secteur, du rôle décisif des tutelles publiques qui, implicitement, définissent les positions professionnelles suffisamment rémunératrices et régulières pour se maintenir en activité. Faute d'un accès suffisant à ces ressources rares et convoitées, les comédiens enquêtés sont en effet condamnés à un exercice irrégulièrement salarié de leur métier ${ }^{5}$, qu'ils jugent en outre souvent altéré dans son contenu.

Dans un premier temps, je décrirai l'engagement des comédiens enquêtés dans le secteur théâtral, où ils connaissent fréquemment des conditions d'emploi instables, marquées par la répétition du travail non rémunéré. Leur cas est à ce titre exemplaire d'un défaut de reconnaissance salariale du travail artistique dès lors que l'on s'éloigne des régions les plus institutionnalisées de l'espace théâtral. Comme on le verra dans un deuxième temps, cette caractéristique de leurs emplois a des incidences non seulement sur leur stabilisation professionnelle mais aussi sur le contenu de leur pratique. On verra enfin que cet éloignement des conditions les plus favorables d'exercice du métier se prolonge pour certains

5 Le terme de métier est polysémique. Synonyme dans la langue courante d'occupation professionnelle, il désigne dans son acception première à la fois un artisanat, relevant d'un apprentissage, et la communauté professionnelle qui le reconnaît. De même qu'ailleurs, cette conception « patrimoniale de la qualification ser[t] de support à la construction d'un schéma de lecture critique du travail et de l'ordre de la production dans une économie de marché » (Piotet $2002: 5$ ), le « métier » soutient ici la défense identitaire d'une exigence technique ignorée par certaines configurations d'emplo jugées dégradées (sur cet aspect, voir aussi Champy 2009 : 100-102). professional situation, but also of the decisive role played by the state at the heart of this sector, which involves implicitly defining the professional positions that warrant the sufficient remuneration and regularity needed to stay in business. Owing to a lack of sufficient access to these rare and coveted resources, the interviewed actors are effectively sentenced to practising an inconsistently paid trade $(\text { métier })^{5}$, which they deem, on top of this, to be often altered in its content.

In the first section of this article, I will describe the interviewed actors' professional experience in theatre-in which it is common to work in unstable conditions without a regular income. Their case is exemplary of a lack of financial recognition for artistic work as soon as we move away from the more institutionalized realms of the theatrical space. As we will see in the second section, this feature of their jobs has an impact not only on their professional stability but also on the content of their work. Finally, we will see that this distancing from more favourable conditions in the profession continues, for some of those interviewed, into adjacent jobs, which distracts them from their traditional artistic practice(s)

5 The French term métier is polysemous. Synonymous in everyday language with professional occupation, it designates first and foremost both an artisanal practice, requiring a learning process, and the relevant professional community. As elsewhere, this "patrimonial [conception] serves as a support for a critical reading scheme of the work and the production order in a market economy" (Piotet 2002: 5). This term is in support of the identity defence of a technical requirement ignored by certain job configurations that are deemed to be downgraded (see also Champy on this aspect, 2009: 100-102). 
d'entre eux par des occupations limitrophes qui détournent les techniques du comédien de leurs finalités artistiques traditionnelles. Ce détournement technique s'articule avec la faible valorisation et la marginalité professionnelle de ces emplois par rapport aux réseaux les plus intégrateurs.

\footnotetext{
Caractéristiques des comédiens interrogés

L'échantillon des 28 individus interrogés n'a pas été établi en suivant a priori une représentativité de la population des comédiens en France. Le recueil des témoignages a permis, en suivant une méthode inductive, de mettre au jour la plus grande diversité de situations sur le marché du travail, que celles-ci aient concerné directement les enquêtés ou qu'ils en aient seulement été les témoins.

\section{Répartition sexuelle et âge}

On compte autant de femmes que d'hommes parmi les comédiens rencontrés. La plus jeune personne interrogée a 28 ans, la plus âgée 60 . En s'ajustant à la date d'insertion professionnelle et en s'intéressant aux communautés d'expérience relatées dans les entretiens, on peut identifier une première génération née au début des années 1980 (de 28 à 30 ans : 5), une autre, déjà plus éloignée de sa période de formation, née au milieu des années 1970 (35 à 41 ans : 8). Ces deux groupes d'âge ont en effet connu une professionnalisation dans les années 2000, marquée par la fin d'une époque jugée plus facile par leurs aînés. Ces derniers qui avoisinent la cinquantaine (46 à 54 ans : 10) ou s'approchent de l'âge de la retraite (de 55 à 60 ans : 5) témoignent d'une trajectoire initiée dans les années 1980 et 1990, c'est-à-dire un contexte plus confortable pour les comédiens, en raison de l'essor du financement culturel et de l'indemnisation par l'assurance chômage.
}

and purpose(s). This diversion accompanies the lack of recognition as well as the professional marginality of these jobs, compared with more integrative networks.

Characteristics of the actors interviewed in this study

The sample of twenty-eight individuals interviewed was not established as an a priori representation of the acting population in France. The collection of accounts using an inductive methodology resulted in the exposure of the breadth of the diversity of situations in the job market, whether directly those of the individuals chosen for the study, or those they have solely witnessed.

\section{Age and gender distribution}

The number of male and female actors in the study is equal. The youngest person interviewed is 28 years old, the oldest is 60 . Focusing on the year of entry into the profession and communities of experience related in the interviews, we can group together a first generation born at the beginning of the $1980 \mathrm{~s}$, who are around 30 years old (28 to 30: five actors). Another group was born in the mid-1970s, and thus their training years are slightly further behind them (35 to 41: eight actors). These two age groups attained professional status in the 2000 s, which is seen as the end of an era deemed to be "easier" by their elders. The latter are around 50 years old ( 46 to 54 : ten actors) or approaching retirement age (from 55 to 60: five actors); their initial trajectory took place in the more comfortable context of the 1980s and 1990s, both in terms of cultural funding and unemployment compensation possibilities. 


\section{Origine sociale}

L'origine sociale des comédiens interrogés, saisie à partir des catégories socioprofessionnelles de leur père, ne s'écarte pas de façon significative de celle des comédiens en exercice, du moins si l'on se réfère, faute de données plus récentes, à l'enquête de 1994 menée par Pierre-Michel Menger et son équipe (Menger $1997: 34$ et 401).

Comme dans la population totale de comédiens, les individus de notre échantillon présentent majoritairement une origine sociale élevée : 13 ont un père dont l'activité relève de la catégorie «Cadres et professions intellectuelles supérieures » soit $46,5 \%$ (contre $49,5 \%$ de la population totale de comédiens). De même, les fils et filles d'artisans et commerçants (ou assimilés) sont nombreux : 6 (soit 21,5\% contre $16,5 \%$ de la population totale de comédiens) ; 5 d'entre eux ont un père relevant de la catégorie des professions intermédiaires (presque $18 \%$, ce qui équivaut aux données concernant la population totale de comédiens). Enfin, 3 ont un père ouvrier $(11 \%$ contre $10 \%$ de la population totale de comédiens). Dans un seul cas, le père est agriculteur exploitant (soit 3,5\% contre $2 \%$ de la population totale de comédiens). Enfin, aucun comédien n'a de père employé (contre $3 \%$ de la population totale de comédiens) ou sans activité professionnelle $(0,1 \%$ de la population totale de comédiens). Parmi les enfants de «Cadres et professions intellectuelles supérieures », en outre, on recense 3 comédiens interrogés dont le père est artiste, ce qui est davantage que dans la population de comédiens (11\% contre $6 \%$ ) et, parmi eux, un dont le père est comédien $(3,5 \%$ contre $2 \%)$.

C'est quand on considère l'activité de leur mère que l'origine sociale des comédiens interrogés s'écarte de celle des comédiens en exercice. Ainsi, la part de mères dont l'activité correspond à la catégorie « Cadres et professions intellectuelles supérieures » est surreprésentée par rapport aux données concernant la population totale de comédiens

\section{Social origin}

The social origin of the actors interviewed in the study (determined by their father's socio-professional status) does not deviate significantly from that of other practising actorsat least if we refer to a survey conducted in 1994 (for lack of more recent data) by Pierre-Michel Menger and his team (Menger 1997: 34 and 401).

As in the total population of actors, the individuals in our sample mainly have a relatively high social origin: following the French classification of professions and socioprofessional categories (PCS) by INSEE [Institut national de la statistique et des études économiques], thirteen (or $46.5 \%$ ) have a father whose activity falls within the category of managerial and professional occupations, (against $49.5 \%$ of the total population of actors). Similarly, there are many sons and daughters of artisans and traders (or similar): six actors (or more than $21.6 \%$ against $16.5 \%$ of the total population of actors). Five actors have fathers in the "intermediate" professions category (almost 18\%, which is equivalent to the data on the total population of actors). Three have working-class fathers (less than 11\% compared with $10 \%$ of the total population of actors). The father of one actor was a farmer (or $3.5 \%$ against $2 \%$ of the total population of actors). Finally, none of the actors has a father who was an employee (against 3\% of the total population of actors) or without professional activity $(0.1 \%$ of the total population of actors). There are three interviewed actors whose father was employed in the arts, which is more than the total population of actors (less than $11 \%$ against $6 \%$ ), and among them, one whose father was an actor (3.5\% against $2 \%)$.

The social status of the practising actors starts to deviate from the total population of actors when we observe their mother's professional activity. Mothers whose activity corresponded to the category of managerial and professional occupations are overrepresented here(eight interviewed actors, or $28.5 \%$, against $19 \%$ ). Among this 
(8 soit $28,5 \%$ contre $19 \%$ ). Parmi ces dernières, les femmes artistes sont également surreprésentées (4 soit $14 \%$ contre $4 \%$ dans la population de comédiens). Parmi ces mères artistes, 1 est comédienne (3,5 \% contre $2 \%$ ). Les enquêtés dont l'activité de la mère relève de la catégorie artisans, commerçants et chefs d'entreprise sont également relativement nombreux (4 soit $14 \%$ contre $8 \%$ de la population totale de comédiens). Leurs mères sont auss moins souvent des employées (4 soit $14 \%$ contre $17 \%$ ) ou sans activité professionnelle (7 soit $25 \%$ contre $36 \%$ ). Les agricultrices exploitantes, en revanche, sont à peine plus nombreuses dans notre échantillon (1 soit 3,5\% contre $1 \%$ ). Seuls les mères appartenant aux professions intermédiaires se retrouvent dans les mêmes proportions (4 soit 14 \%).

\section{Origine géographique}

Un peu plus de la moitié des individus interrogés habite Paris (14) ou l'île-de-France (1), les autres résident en province : Lyon (7), Marseille (3), Bordeaux (1), Caen (1) ou encore un village (Normandie [1]). Notons cependant qu'au moment de l'entretien, deux des Parisiens s'interrogent alors sur un possible retour en province où ils ont travaillé auparavant. Seuls 7 enquêtés sont originaires de Paris, les autres sont nés pour la plupart dans de grandes villes de province, plus rarement dans de petites communes, et une seule enquêtée est née à l'étranger (ancienne colonie française).

\section{Formation et intégration en agence artistique}

Un quart des artistes interrogés (7) sont autodidactes, mais se sont perfectionnés par la voie des stages professionnels. Ils sont 3 à avoir suivi une formation seulement dans un conservatoire municipal ou régional, et 1 dans une école supérieure étrangère. 14 ont été formés dans des cours privés (en plus - pour 5 d'entre eux - de cours en conservatoire municipal ou régional), tandis que 2 ont suivi la classe libre du cours Florent dont le concours est prisé et sélectif (Katz 2006). Seuls 4 comédiens ont été formés dans l'une des onze group, employment in the arts is also overrepresented (four actors, or $14 \%$, against $4 \%$ in the total acting population). Among these jobs, one was an actress (3.5\% against $2 \%$ ). The actors whose mothers fall into the artisans, traders, and company managers category are also relatively high in number (four actors, or $8 \%$ of the total population of actors). Also fewer in number are the mothers who were employees (four actors, or $14 \%$ against $17 \%$ ), or unemployed (seven actors, or $25 \%$ against $36 \%$ ). Farmers amongst the group are somewhat overrepresented $(1$, or $3.5 \%$ against $1 \%)$. Mothers in the "intermediate occupations" category are equal in both sets of figures (four actors, or 14\%).

\section{Geographical origin}

Slightly more than half of the interviewed individuals live in Paris (fourteen) or the Île-de-France region (one). The others live in the following cities: Lyon (seven), Marseille (three), Bordeaux (one), Caen (one), and a village in Normandy (one). It is important to note, however, that two of the Parisians are in an uncertain situation with regards to moving from Paris back to smaller towns where they previously worked. Only seven are originally from Paris, the majority of the others were born in other cities, or, less frequently, smaller towns, and just one was born abroad (in a former French colony).

\section{Training and integration in talent agencies}

The interviewed actors also have various trajectories in terms of training. Seven are self-taught, but received further training through professional internships. Three trained at a municipal or regional conservatoire and at a foreign institution. Fourteen received training through private theatre classes: among them, five from private schools combined with a local or regional conservatoire, while two followed the Cours Florent Classe libre, which is very prestigious and selective (Katz 2006). Four of them trained at one of 
écoles supérieures d'art dramatique habilitées à délivrer le diplôme national supérieur de comédien. II est à noter qu'aucun n'a suivi un parcours au sein d'une école nationale dépendant du ministère de la Culture (école du TNS ou CNSAD), les modalités de prise de contact avec les enquêtés n'ayant jamais permis d'atteindre de tels profils d'individu. Sur les 28 enquêtés, 5 individus sont représentés par une agence de talent (signe de l'accès à un certain degré de visibilité dans le secteur audiovisuel), et ce fut le cas pour 2 d'entre eux par le passé. Mais la grande majorité, soit 21, n'a jamais connu cette situation.

\section{Situation au regard de l'assurance chômage}

Les trois quarts des individus interrogés se trouvent, au moment de l'entretien, dans une situation d'exclusion des indemnités chômage (21 sur 28). On recense 3 enquêtés qui déclarent avoir renoncé à poursuivre leur activité, mais il est difficile de statuer avec certitude sur les effets de ces décisions. En revanche, 7 comédiens ont été rencontrés après avoir recouvré leurs droits. Pour ces derniers, la période de non indemnisation s'est étalée de 5 mois à plus de 2 ans.

\section{Revenus}

Par souci de ne pas réduire les entretiens à un échange aussi peu fécond que pénible vu les situations critiques expérimentées par certains enquêtés, le chiffrage des revenus annuels n'a pu être établi que de façon approximative, excepté pour 6 individus, dont les réponses ont été trop évasives. Les 7 personnes ayant recouvré leurs droits déclarent des revenus moyens inégaux sur les années précédentes. Au plus fort de leur activité, ces revenus, assurance chômage incluse, sont compris entre 1200 et 2500 euros par mois. Mentionnons à part le cas d'un comédien, actif principalement pour la télévision, dont les revenus annuels varient entre 55000 et 255000 euros : son activité, prospère, n'est toutefois pas nécessairement assidue - raison pour laquelle il a été interrogé. Sur les the eleven écoles supérieures d'art dramatique permitted to grant the national acting diploma. It is worth noting that none of the interviewed actors was trained within one of the national schools under the Ministry of Culture (the École du Théâtre national de Strasbourg, known as "TNS," or the Conservatoire national supérieur d'art dramatique, CNSAD): the selection process we used to recruit interviewees did not allow us to contact these individuals. Five individuals from our sample are presently represented by a talent agency, and two have previously worked with agencies. The clear majority (twenty-one actors) have never been in this situation.

\section{Unemployment compensation}

Three quarters of the individuals interviewed were not receiving unemployment compensation at the time of the interview (twenty-one out of twenty-eight). Three interviewees claim to have stopped relying on the continuation of their professional activity, but it is difficult to determine for certain the impact of these decisions. Seven actors interviewed, however, had regained their rights to unemployment benefits. Among these, the minimum period of non-compensation was five months, and the longest was more than two years.

\section{Income}

To avoid reducing interviews to an unfruitful and, in many critical situations, impossible exchange of protocol, amounts for actors' income per annum could not be established with precision, but were calculated approximately. Six individuals responded in a way which was too evasive to be evaluated. The seven people who regained their rights claim to have received an uneven average income in previous years. At the peak of professional activity, this income (including unemployment benefits) ranged from 1,200 to 2,500 euros per month. We could single out the case of one actor who works principally in television, whose annual income varies between 50,000 and 255,000 euros: his professional activity, although prosperous, is not, however, necessarily regular, which is why he was interviewed. Out of the twenty-one 
21 comédiens qui n'ont pas recouvré leurs droits, leurs revenus étaient de 1000 à 2000 euros mensuels, lorsque leur activité était la plus soutenue. Leur situation s'inscrit donc sans départir dans le tableau plus général du revenu des artistes du spectacle et des comédiens en France. En 2011, d'après l'Unédic, le revenu annuel médian des artistes intermittents du spectacle est de 21859 euros, soit environ 1800 euros mensuels. La part des indemnités d'assurance chômage représente 51 \% du revenu global (Gille 2013 83-84). Ces données correspondent à ce que l'on connaît plus spécifiquement des comédiens d'après les données du groupe Audiens. Sur une population de comédiens indemnisés au titre de l'assurance chômage sur une période au moins chaque année, entre 2009 et 2011, la médiane des salaires est de 10000 euros par an (Katz 2015).

\section{La vocation théâtrale au risque du travail gratuit}

Le spectacle vivant : centre de gravité du marché de l'emploi

La représentation dominante du comédien est sans doute celle de la star de cinéma. Cette évocation spontanée, issue d'une fascination courante pour les acteurs portés au pinacle par les grands médias, ne correspond pas à la situation des comédiens interrogés dans le cadre de notre enquête. Qu'estce à dire exactement ? D'abord, leur intégration professionnelle initiale résulte d'engagements réguliers dans le spectacle vivant : contrairement aux acteurs les plus célébrés, ils n'ont exercé que marginalement leur activité dans les secteurs du cinéma ou de la télévision. Leur parcours exprime ainsi un trait dominant du marché du travail, à savoir la situation centrale du actors who had not received their unemployment rights, their income at the peak of their professional activity ranged from 1,000 to 2,000 euros per month. Their situation is in line with the more general income information for intermittent performers and actors in France. In 2011, the global annual median income for intermittent performers was 21,859 euros, or around 1,800 euros per month. The proportion of unemployment benefits is a major part of this global income total. Wages in fact represent less than 49\% (Gille 2013: 8384). These data correspond to what is specifically known about actors according to the Audiens group database. On a population of actors who received compensation for at least one period in each year between 2009 and 2011, the median wage is 10,000 euros (Katz 2015).

\section{The vocation of theatre at the risk of free labour}

\section{Live performance-gravitational centre of the employment market}

The dominant representation of an actor is arguably the movie star. This spontaneous evocation, which derives from a prevalent fascination with actors put in the limelight by mainstream media, does not correspond with the situation of the actors interviewed as part of our investigation. What does this imply, exactly? Firstly, their initial professional integration is the result of regular experience in live performances. Unlike more famous actors, they have only marginal experience in cinema and television. Their career paths therefore illustrate a dominant feature of the employment sector, namely the theatre's central position in providing a greater quantity 
théâtre pour fournir globalement à l'ensemble des comédiens une quantité supérieure d'activité ${ }^{6}$. Cette réalité est confirmée par les données agrégées par le groupe de protection sociale Audiens sur le montant global des salaires ${ }^{7}$ : il est ainsi révélateur que, pour les comédiens ayant été indemnisés par l'assurance chômage sur une période chaque année, en 2009, 2010 et 2011, la part moyenne des salaires issus de leur activité artistique dans le spectacle vivant soit majoritaire (autour de $60 \%$ des salaires) et bien supérieure à celle des comédiens qui, faute d'un volume d'activité suffisant, ne sont plus assurés en 2011. Pour ces derniers, cette part suit même une pente descendante sur les trois années $(44 \%, 34 \%$ puis $30 \%$ des salaires), alors que la part de leurs salaires issus de l'activité artistique dans le secteur audiovisuel augmente. Ainsi le spectacle vivant, du fait du volume global d'activité qu'il fournit, apparaît comme relativement stabilisateur dans l'indemnisation chômage. II n'est par conséquent pas surprenant que les périodes de stabilisation professionnelle de la quasi-totalité des comédiens interrogés résultent de l'emploi dans ce secteur.

«Centre de gravité du marché de l'emploi » (Menger 1997 : 207), le théâtre est au cœur des réseaux qui structurent les échanges professionnels de ces comédiens. Si quasiment

6 Le volume total de travail dans les théâtres représente $75 \%$ du volume tota de l'emploi déclaré par les comédiens (Menger 1997 : 207).

7 Dans le cadre de la gestion, depuis 2003 , de la retraite complémentaire des professionnels de l'audiovisuel, de la communication, de la presse et du spectacle, Audiens reçoit annuellement les déclarations nominatives des salaires de la part des entreprises de ces secteurs d'activité. of professional activity to actors in general ${ }^{6}$. This reality is confirmed by data gathered by Audiens on average wages ${ }^{7}$. While these data do not concern the amount of activity but the total sum of wages, they reveal that, for actors who received unemployment insurance for at least one period each year between 2009 and 2011, the majority of their wages earned through artistic activity was from live performances (around $60 \%$ ), and this was much higher than that of those actors who were no longer insured in 2011 for want of sufficient professional activity. The latter group has seen a decline of this share over the last three years $(44 \%, 34 \%$, and $30 \%$ of wages). Meanwhile, the share of their income from artistic activity in the audiovisual sector has increased. Therefore, live performance appears to be a relative stabilising sector when receiving unemployment benefits. It is therefore unsurprising that almost all the actors interviewed in the study found periods of stable professional employment in this sector.

As the "gravitational centre of the employment market," theatre is at the heart of the networks that organize these actors' professional exchanges (Menger 1997: 207). While

6 The total amount of work in theatres represents $75 \%$ of the total amount of work declared by actors (Menger 1997: 207).

7 In the context of management, since 2003, Audiens has received nominative salary declarations of the supplementary pension of professionals in the audiovisual, communications, media, and entertainment sectors. 
aucune organisation intégrée ${ }^{8}$ n'assure en France la permanence de l'emploi au théâtre (pas plus dans ce secteur qu'au cinéma ou à la télévision), les expériences de travail s'y étalent néanmoins sur de plus longues périodes que dans l'audiovisuel. Comme en témoignent les enquêtés, l'activité théâtrale suppose un investissement subjectif soutenu et une inscription dans une expérience collective qui, en de nombreux moments, outrepasse le temps de l'emploi : rencontres entre collaborateurs, lectures communes, continuité des répétitions, réitération des représentations, voire réaménagements de spectacle lors des tournées et reprises.

Le projet commun que représentent l'élaboration et la réussite des spectacles trouve du reste souvent son prolongement audelà des spectacles eux-mêmes, dans la consolidation des collectifs de travail. Et si la division du travail entre metteur en scène et comédiens correspond la plupart du temps à la partition entre recruteur et recrutés, l'enjeu supérieur de l'investissement collectif tend à masquer ces inégalités bien réelles de position (Menger 1997 ; Lambert 1998 ; Proust 2003 ; Bense Ferreira-Alves 2006). Sans exclure les éventuels tensions et rapports de force, les relations

8 La Comédie-Française reste à ce jour le seul théâtre avec un personnel artistique permanent en France. La question de l'emploi permanent des comédiens dans les théâtres en France, à l'instar de ce qui existe en Allemagne (Katz 2005 ; Verdalle (de) 2006), est une revendication prise en compte dans un accord conclu le 26 mai 2003 entre le Syndicat des entreprises artistiques et culturelles, et l'ensemble des organisations syndicales de salariés, mais sans application véritable. Cette question est aussi régulièrement posée par certains metteurs en scène actifs dans les théâtres nationaux et les centres dramatiques nationaux - tel Christian Schiaretti, qui a initié il y a quelques années l'expérience d'une troupe intégrée au Théâtre national populaire de Villeurbanne. almost no integrated organization ${ }^{8}$ in France provides permanent jobs in theatre (no more than for cinema or television), professional experience is nevertheless spread out over longer periods of time than in the audiovisual sector. As the interviewees explain, theatre activity implies sustained personal investment and subscribes to a collective experience which often exceeds working hours: meetings with collaborators, communal readings, rehearsals, repeated performances, and even making rearrangements during tours and show times.

The communal project representing the development and success of a production is continued by the consolidation of work collectives. While the division of labour between director and actors primarily corresponds to the division between employer and employees, the main stake of collective investment tends to hide these very real positional inequalities (Menger 1997; Lambert 1998; Proust 2003; Bense FerreiraAlves 2006). Notwithstanding tensions and power struggles that may arise, close affinities are often formed by way of consistent professional engagements: the use of the term

8 The Comédie-Française remains to this day the only theatre in France with permanent artistic staff. The question of permanent jobs for actors in French theatres (like the German example [Katz 2005; Verdalle (de) 2006]) is a claim that arose in an agreement on 26 May 2003 between the Syndicat des entreprises artistiques et culturelles and all the employee trade unions, but did not achieve tangible results. This issue is also regularly reinstated by certain directors active in national theatres [théâtres nationaux and centres dramatiques nationaux] - such as Christian Schiaretti, who initiated the creation of a theatre company into the Théâtre national populaire de Villeurbanne several years ago. 
personnelles qui pourvoient à la régularité des engagements des individus rencontrés sont ainsi marquées par une grande proximité affinitaire : le mot de « familles » qu'ils utilisent rend bien compte du registre affectif de ces relations de travail

(Paradeise 1998).

\section{Le travail gratuit : un dépassement de la subordination salariale?}

Un trait est caractéristique de cette économie affinitaire des relations de travail : suivant l'inclination de ces « amitiés professionnelles ", pour reprendre l'expression d'une comédienne, quasiment tous les individus interrogés acceptent, à un moment ou un autre, de contribuer au travail de création sans être rémunérés. Certes, la part gratuite fournie dans le travail est variable selon les comédiens, leurs réseaux, la nature de l'activité et les segments professionnels; mais ce phénomène, qui a été interprété diversement (Pilmis 2012 ; Cardon \& Pilmis 2013 ; Grégoire 2013), mérite d'être à nouveau souligné. Le non-paiement ou le paiement partiel des répétitions, la contribution bénévole aux opérations techniques ou logistiques, le partage de la seule recette ou l'investissement totalement gracieux dans un projet, dans l'espoir d'une rétribution très différée, correspondent à la dénégation du droit du travail pour des tâches et des opérations techniques explicitement mentionnées dans les diverses conventions collectives en vigueur ${ }^{9}$.

9 Assimiler ces tâches et opérations techniques à du travail « invisible » (Corsani \& Lazzarato 2008 : 92), c'est donc contribuer à l'invisibilisation de normes juridiques, dont l'application et l'existence sont précisément un enjeu conflictuel dans la délimitation du travail salarié "families" highlights the emotional register of these working relationships (Paradeise 1998).

\section{Working for free: overtaking the subordination of wage-earners?}

A characteristic trait of this economy built on good working relationships is that almost everyone interviewed admitted to having worked without being paid at some point, following a trend of "professional friendships," in the words of one actress. Certainly, the portion of unpaid work varies depending on the actor, their networks, the nature of their work, and the professional sector. But this phenomenon, with its diverse interpretations (Pilmis 2012; Cardon \& Pilmis 2013; Grégoire 2013), deserves to be highlighted once more. Non- or partial payment for rehearsals, volunteer contributions in technical or logistic operations, collective sharing of takings, or totally investing one's time freely in a project in the hope of later payment correspond to denying employment rights for tasks and technical operations explicitly planned by various collective conventions put in place ${ }^{9}$.

9 Analysing these tasks and operational techniques as "invisible" work therefore participates in making the legal standards more invisible, where their application and existence are precisely a divisive issue in defining paid work (Corsani \& Lazzarato 2008: 92). 
Les comédiens enquêtés sont nombreux à accepter cet investissement non payé. L'amour d'un texte, l'affinité avec les porteurs de projet, l'adhésion au collectif de travail sont alors les premières motivations énoncées. La justification du travail non rémunéré paraît ainsi correspondre à une rhétorique vocationnelle qui conteste toute importance au gain financier et affirme la gratuité du geste artistique, contre la contrainte commerciale ou la routine du travail salarié (Bourdieu 1971; Sapiro 2007). Cependant, l'approfondissement de cette question au cours des entretiens révèle aussi qu'intérêt artistique et intérêt économique ne s'opposent jamais complètement. Ne serait-ce que parce qu'il s'agit a minima, pour le comédien, de chercher à pérenniser sa position professionnelle au sein de réseaux où ses aspirations artistiques trouveraient à se réaliser. En ce sens, l'implication désintéressée dans un projet ne s'avère gratuite qu'à court terme. Cette forme d'engagement dans le travail s'inscrit en effet dans un pari sur l'avenir professionnel, aux consonances matérielles vite évidentes. Le travail non rémunéré est conçu comme un investissement qui doit fournir un retour à moyenne échéance - perspective de recettes, espoir d'un achat de spectacle, pari sur le réseau de jeunes metteurs en scène perçus comme prometteurs (Pilmis 2012 ; Cardon \& Pilmis 2013). Du reste, l'indemnisation chômage est couramment mobilisée pour assurer le risque pris ${ }^{10}$.

10 Les indemnités de chômage des intermittents du spectacle représentent, de façon globale, un complément économique de $20 \%$ du budget des compagnies - après un croisement des données statistiques collectées et celles de l'Unédic - instance chargée, en France, de la gestion de l'assurance chômage (Urrutiaguer, Henry, Duchêne 2011).
Many of the actors interviewed have accepted such an unpaid commitment. The primary motivations are out of love for a production, an affinity with project leaders, or belonging to a collective work group. Justification for unpaid work seems to correspond to a vocational rhetoric that rejects the importance of financial gain and affirms the free price tag of artistic work against the commercial constraints or the routine of wage labour (Bourdieu 1971; Sapiro 2007). However, if we observe the interviews on this issue in greater depth, we can see that artistic and material interests are never completely opposed. Actors must sustain their professional position within networks where their artistic aspirations are likely to be met. In this way, disinterested involvement in a project turns out to be free only in the short term. This form of professional engagement seems to be like betting on one's professional future, with all the obvious financial implications resounding loudly. Unpaid work is construed as an investment that must provide financial return within a relatively short period of time - the prospect of income, the hope of a bid for a theatre show, bets on the network of young directors deemed as promising, and so on (Pilmis 2012; Cardon \& Pilmis 2013). Moreover, unemployment payments are commonly used to cover the risk taken ${ }^{10}$.

10 Unemployment benefits in show business generally represent a financia supplement of $20 \%$ of company budgets-according to collected statistics and data from Unédic the association in charge of the management of unemployment insurance in France (Urrutiaguer, Henry, Duchêne 2011) 
Ce dernier élément illustre le caractère exceptionnel du régime des intermittents du spectacle (Menger 2011). II atteste aussi de l'emprise des institutions salariales sur la régulation de l'activité artistique, ce que retrace bien Mathieu Grégoire (Grégoire 2013). Ce dernier, en prolongeant les arguments de Bernard Friot (Friot 1998), voit même dans ce recours étendu au salaire socialisé la marque d'un contre-pouvoir des travailleurs intermittents. L'articulation entre discontinuité des contrats et régime spécifique d'indemnisation chômage, qui instaure un décalage entre emploi, travail et rémunération, donnerait auxartistes la liberté de définir leurs investissements, si nécessaire en choisissant de ne pas recourir à l'emploi salarié ${ }^{11}$

Certains équilibres temporaires trouvés par quelques comédiens interrogés semblent à première vue l'illustrer. Une comédienne est ainsi engagée par un grand théâtre lyrique parisien en tant que chanteuse de second rang, avec salaires réguliers et répétitions payées. Ce contrat lui procure quelques années l'assise matérielle et une quantité suffisante de cotisations à l'assurance chômage. Dans ces conditions, elle peut s'investir dans d'autres projets qui ne sont rémunérés que pour la représentation :

$$
\begin{aligned}
& \text { « - Quand on est payé } 200 \text { euros brut par } \\
& \text { représentation pour ce genre de projets de } \\
& \text { petite compagnie, [...] c'est vraiment pas mal. } \\
& \text { - Vous ne pourriez pas faire que ce genre de choses? }
\end{aligned}
$$

11 Un tel modèle est cependant théorisé à partir des conditions d'indemnisation plus généreuses prévalant avant la réforme de 2003. Sur cette question, voir aussi Langeard 2013.
This last factor illustrates the exceptional character of the entertainment industry (Menger 2011 [2005]). It also attests to the influence of wage institutions on the regulation of artistic activity, which Mathieu Grégoire retraces well (Grégoire 2013). Building upon Bernard Friot's arguments (Friot 1998), Grégoire sees this extended use of social wages by intermittent artists as a kind of counter-force. The distinction of the discontinuity between contracts and the specific unemployment benefits regime (which introduces disparity between job, work, and pay) would give artists the freedom to define their own investments, if necessary, by choosing to exceed paid employment ${ }^{11}$.

The temporary stability enjoyed by some of the actors interviewed seems to illustrate this at first glance. For example: an actress is hired by a large Parisian opera company as a secondary-ranking singer, with regular wages and paid rehearsals. This contract gives her a couple of years of financial stability and enough contribution to her unemployment insurance. Under these conditions, she can invest time in other projects that are only paid for per show:

"- When we are paid 200 euros gross per show for this type of small company project, [...] this is really not that bad." - You couldn'tjust do these kinds of things, though, could you? - Oh no, but that's why without the Théâtre-Lyrique [a

11 However, such a model is theorized from the more generous compensation conditions dating from before the 2003 reform. For further information on this question, see Langeard 2013. 
- Ah non, mais c'est pour ça que [...] sans le ThéâtreLyrique [grand théâtre parisien], j'étais hors circuit. " (Christine B., 46 ans, comédienne, formée en cours privé, exclue depuis un an de l'indemnisation chômage en janvier 2012, vit à Paris.

Une autre enquêtée présente régulièrement, dans des cafésconcerts, un spectacle de cabaret rémunéré à la recette. Ce sont toutefois ses contrats pour des créations produites par des centres dramatiques nationaux ${ }^{12}$ et des théâtres municipaux de grandes villes qui alimentent son indemnisation chômage :

«Moi, [...] être dans des réseaux subventionnés, ça m'a permis d'être dans des trucs pas payés. Je m'en foutais. Pour moi, l'intermittence [sic], ça sert quand mêmeà ça. C'est-à-dire que ça sert justement à faire des créas non subventionnées. Moi je suis subventionnée par l'État [sic], donc peu importe si je suis pas payée quelquefois, finalement. II faut juste pas

12 Les théâtres nationaux, les centres dramatiques nationaux (CDN) et régionaux (CDR) et les scènes nationales forment en France le réseau principal du théâtre public, soutenu financièrement, bien que partiellement, par l'État. D'autres structures, dont certains théâtres municipaux, relèvent de financements publics, dont, en partie, de subventions du ministère de la Culture. En 2011, les quatre théâtres nationaux totalisent un peu moins de 60 millions d'euros de subventions du ministère de la Culture et sont financés à $28 \%$ sur des ressources propres. Les 39 CDN et CDR captent 60,9 millions d'euros d'aide de l'État qui les finance à hauteur de $56 \%$ (28\% de leur budget provient des communes, $9 \%$ des régions et $7 \%$ des départements). Enfin, les 69 scènes nationales sont financées à hauteur de $24 \%$ par l'État (moins de 10 millions d'euros). Leur financement provient sinon des villes et communautés urbaines $(34 \%)$, des départements $(9 \%)$, des régions $(7 \%)$, d'autres aides $(1 \%)$ et de leurs recettes propres $(25 \%)$ (Source : Chiffres clés 2013 - statistiques de la Culture. Ministère de la Culture et de la Communication.) large Parisian theatre] [...] l'd have been out of business." (Christine B., 46 years old, actress, lives in Paris, trained in private schools, excluded from unemployment benefits for one year in January 2012.)

Another interviewee performs a regular cabaret show in live music cafes, where the pay depends on takings. It is nonetheless the creative contracts produced by centres dramatiques nationaux (national drama centres) ${ }^{12}$ and municipal theatres in big cities that feed into her unemployment compensation:

"Being within subsidized networks basically allowed me to take part in unpaid stuff. I didn't care. If you ask me, that's what intermittent status is all about. I mean, it's supposed to be for non-subsidized creations. I am subsidized by the state, so in the end it doesn't matter if I don't get paid sometimes. This can't just go on for too long though, like, this year, suddenly, I'm broke and I can't do anything anymore."

12 The théâtres nationaux, centre dramatiques nationaux (national drama centres, CDNs), centres dramatiques régionaux (regional drama centres, CDRs), and scènes nationales (public theatres) make up the main network of public theatres in France which are entirely or partially funded by the state. Other structures, including some municipal theatres, receive public funding - subsidies from the Ministry of Culture, among other institutions. In 2011, the four théâtres nationaux received a total of just under 60 million euros in Ministry of Culture subsidies, and were $28 \%$ funded from their own resources. The thirty-nine CDRs and CDNs received 60.9 million euros in state funding $-56 \%$ of their budget (28\% came from municipalities, $9 \%$ from the region, and $7 \%$ from the department). Finally, the sixty-nine scènes nationales received state funding of up to $24 \%$ (less than 10 million euros). Their funding otherwise comes from cities and urban communities (34\%), departments $(9 \%)$, regions $(7 \%)$, other sources of aid $(1 \%)$, and their own revenue (25\%) (source: Culture and Communication Ministry statistics 2013). 
que ça dure, comme là, cette année, où tout d'un coup, je suis prise à la gorge et je ne peux juste plus rien faire. ” (Élodie E., 29 ans, comédienne, formée à l'ENSATT ${ }^{13}$, exclue depuis cinq mois de l'indemnisation chômage en mars 2013, vit à Lyon.)

L'expérience est similaire pour un comédien qui est régulièrement engagé sur des petites apparitions dans un grand théâtre municipal de province. Cet engagement récurrent soutient ses projets personnels peu payés pendant

quatre années :

« Je suis arrivé à entrer au théâtre des Jacobins [théâtre municipal], j'ai passé une audition. De 1996 à 2000, j'ai été repris tous les ans aux Jacobins. C'était vraiment un confort. Parce qu'il y avait minimum un mois de répétitions. Cette période, elle était bien. Parce qu'on pouvait faire à côté des trucs beaucoup plus personnels avec une compagnie, des amis. [...] Là c'est des subventions de la ville, mais c'est des grosses subventions, comme l'opéra, quoi. Donc pas mal de moyens. Une pièce, c'était généralement un mois ou cinq semaines de répétitions. Et les pièces qui se jouaient au théâtre des Jacobins, on jouait minimum un mois. Parfois plus, quand c'était des grosses pièces autour de Noël. Alors là, c'était deux mois. » (Michel B., 56 ans, comédien, formé en cours privé et conservatoire municipal parisiens, exclu depuis deux ans et demi de l'indemnisation chômage en mars 2013, vit à Villeurbanne.)

Indéniablement, le régime spécifique d'assurance chômage des intermittents du spectacle assure à ces comédiens une

13 École nationale supérieure des arts et techniques du théâtre, située à Lyon.
(Élodie E., 29 years old, actress, lives in Lyon, trained at ENSATT ${ }^{13}$, excluded from unemployment benefits for five months in March 2013.)

The experience is similar for an actor who is hired regularly for minor roles in a large provincial municipal theatre. This recurring situation helped support his low-paid personal projects for four years:

"I got into theatre through the Jacobins [municipal] theatre. I had an audition there. I was hired there every year from 1996 to 2000. It was pretty comfortable. Because there was a minimum of a month of rehearsals. It was a good period because we could do much more personal stuff with another companies at the same time... with friends [...]. With grants from the city, but big grants, like, y'know, the opera. So, they've got the means. One play meant usually around four or five weeks of rehearsals. The plays put on at the Jacobins theatre ran for at least a month. Sometimes more, for the big plays around Christmas - those were on for two months." (Michel B., 56 years old, actor, lives in Villeurbanne, trained privately and in local Parisian conservatoires, excluded from unemployment benefits for two and half years in March 2013.)

The unemployment insurance system specifically for intermittent artists undeniably provides these actors with a

13 The École nationale supérieure des arts et techniques du théâtre in Lyon. 
autonomie partielle. II leur donne la possibilité temporaire de s'investir dans des projets peu ou pas rémunérés. Mais ces exemples montrent également que l'efficience de ce régime dépend en grande partie de la qualité des emplois qui permettent d'y accéder. II faut en effet souligner les caractéristiques particulières des engagements qui, pour reprendre les expressions citées, ont permis à ces comédiens de se maintenir " dans le circuit » sans être aussitôt « pris à la gorge ". C'est l'intégration à des emplois soutenus par des structures centrales (en l'occurrence théâtre municipal parisien ou de grande ville, centres dramatiques nationaux) suffisamment financées et respectant les normes salariales (définies par les conventions collectives en vigueur), qui leur garantit une stabilisation professionnelle très difficile à atteindre autrement. Ainsi, pour ces artistes, l'exclusion des emplois de ce type signifie à terme la perte de leurs droits à l'indemnisation chômage.

\section{Conditions de travail contraintes à la marge de l'emploi subventionné}

\section{Un accès à l'indemnisation chômage tributaire} de la qualité de l'emploi

Dans ces conditions, on comprend que les relations amicales nouées à l'occasion d'emplois peu reconnus ne puissent tout à fait contenir le désir de rejoindre des réseaux professionnels plus légitimes. Les « grands metteurs en scène », les institutions du théâtre " national ", voire le " théâtre subventionné », suscitent chez les comédiens interrogés une attirance, parfois une fascination, que certain degree of autonomy. It gives them an opportunity to temporarily invest in projects that are poorly paid or indeed unpaid. But these examples also show that the efficiency of this system largely depends on the quality of jobs which allow access to it. It is important to note the special characteristics of these jobs, which, to use the expressions cited, have allowed these actors to stay "in the circuit" without finding themselves suddenly "broke." What guarantees them professional stability - which would otherwise be very hard to attain -is integration into jobs supported by central and sufficiently funded structures with well-regulated salaries (here, a municipal theatre in Paris or a centre dramatique national in a major city). For such artists, being excluded from these types of job ultimately means losing their unemployment benefit rights.

\section{Restricted working conditions on the fringes of subsidized employment}

\section{Access to unemployment compensation depends on the quality of the job}

From this perspective, friendships made while employed in jobs with barely any recognition cannot, of course, entirely satisfy a desire to join more legitimate professional networks. "Great directors," national theatre institutions, and even "subsidized theatres" are most often praised and cited-to the point of fascination-by the actors interviewed, which cannot be explained simply by their symbolic legitimacy. 
n'explique pas seulement leur légitimité symbolique. Dans les parcours décrits, les périodes les plus stables dans l'emploi et l'indemnisation chômage résultent d'engagements réguliers pour des productions avec répétitions payées, réitérations des cachets de représentation lors de tournées et rémunérations relativement satisfaisantes ${ }^{14}$. Ces conditions sont réunies à l'occasion, rare et recherchée, de contrats avec des structures suffisamment dotées : CDN, théâtre municipal d'une grande ville ou, dans une moindre mesure - du fait des remises en causes budgétaires - compagnie régulièrement insérée dans les réseaux de financements publics. À l'inverse, l'engagement par des compagnies peu ou pas subventionnées, des salles privées et même des théâtres privés parisiens, est pour ces comédiens synonyme de précarité, de conditions de travail moins favorables et de tâches non rémunérées et non déclarées :

« J'ai pu faire d'autres spectacles de petites compagnies qui étaient peu subventionnées voire pas subventionnées. Donc, ça donne : travail de répétition en général pas payé. Et après sur les représentations, il y a tous les cas de figure : des cachets, ou pas de cachet, mais c'était à la recette, ce qui m'est arrivé rarement, mais c'est arrivé. Donc là, on travaille parfois gratos. ” (Jeanne C., 53 ans, comédienne, formée en cours privé parisien, a connu une exclusion de l'indemnisation chômage

14 Pour les « mois pleins » (c'est-à-dire les mois sans période de chômage), les comédiens concernés témoignent de revenus compris approximativement entre 2500 et 3000 euros, issus de leur emploi dans les structures publiques. La part entre salaires et allocations chômage étant cependant pour eux difficile à distinguer rétrospectivement au cours des entretiens, il s'agit de leurs revenus globaux.
In the described career paths, the most stable periods in employment and unemployment compensation result from regular commitments to productions with paid rehearsals, regular contracts during tours, and relatively satisfactory remuneration ${ }^{14}$. These conditions are sometimes coupled with well-paid contracts with reputable institutions, but this remains rare and sought after: for instance, a CDN, municipal theatre, or, to a lesser extent-owing to budget constraints - a company that is well placed within public funding networks. On the other hand, the commitment from little or unsubsidized companies, private spaces, and even private Parisian theatres is, for these actors, synonymous with unstable working conditions and spending time in unpaid and undeclared jobs, at least partially:

"Ihavedoneothershowsinsmall companieswhich received very few or no subsidies. So, this means generally unpaid rehearsal work. And then for performances, there are all kinds of cases: paid or unpaid-I've rarely had unpaid work, but it happens. And in that case, yes, we sometimes work for free." (Jeanne C., 53 years old, actress, trained via private classes in Paris, excluded from unemployment compensation for two to three years [exact duration not specified] between 2008 and 2011, became eligible again in May 2012, lives in Marseille.)

14 For the "full months," the actors concerned declare an approximate income of 2,500 to 3,000 euros from their jobs in the public sector. The difference 
comprise entre deux et trois ans [durée exacte non précisée] entre 2008 et 2011, bénéficie de ses droits en mai 2012, vit à Marseille.)

L'hétérogénéité des expériences rapportées au cours des entretiens montre bien que l'activité de ces comédiens - et audelà, des intermittents du spectacle-ne peutêtre appréhendée uniformément à l'aune de la flexibilité de l'activité et de leur régime spécifique de socialisation du risque professionnel. II faut prendre plus précisément en compte la spécificité des emplois régulièrement occupés : la propension inégale des organisations employeuses à respecter les normes salariales en vigueur conditionne fortement l'accès à l'indemnisation chômage. L'autonomie à laquelle aboutit un salarié grâce à ses droits à la protection sociale est ainsi attachée à ses contrats de travail, fût-il intermittent du spectacle. C'est là précisément une des multiples dimensions de la qualification, ici entendue en termes de reconnaissance statutaire d'un poste sur le marché du travail (Rose 2012).

\section{Accéder aux emplois valorisants sans formation valorisée : une trajectoire improbable}

Les différences et les hiérarchies entre les différents secteurs de leur espace professionnel sont très bien perçues par la plupart des comédiens interrogés. Ils savent non seulement définir leur propre positionnement, mais encore l'évaluent par leur distance au réseau des théâtres nationaux et des centres dramatiques nationaux ou, pour les moins intégrés au marché du travail, aux subventions publiques. Dans cette perspective, ils ont raison de faire de leur parcours de formation initiale le
The heterogeneity of the experiences reported during interviews shows that these actors' activity-and beyond that, that of intermittent artists in general-cannot be dealt with in the same way considering the flexible nature of the activity and the specific socialisation process of professional risk. The specificity of regularly held jobs must be considered: the uneven propensity of employer organizations to fully respect salary standards strongly determines access to unemployment compensation. The autonomy sought by employees thanks to social protection rights comes as part of employment contracts, whether or not they have intermittent status. This is one of the multiple dimensions of the unequal statutory recognition of jobs in the employment market (Rose 2012).

\section{Working in qualified employment without having trained at a national school: an unlikely career path}

Most actors interviewed in the sample perceive the differences between professional spaces, and even their hierarchical situations, very well. Not only do they know how to define their own position, but they can also evaluate themselves in relation to their distance from the networks of théâtres

between wages and unemployment compensation is, however, difficult to distinguish retrospectively in the interviews-the sums referred to therefore concern their total income. 
facteur explicatif principal de leur exclusion totale ou partielle de ce qu'ils appellent la « famille du subventionné ». Aucun n'a connu d'engagement dans un théâtre national, aucun non plus n'a fréquenté le Conservatoire national supérieur d'art dramatique (CNSAD) à Paris ou l'École supérieure d'art dramatique du Théâtre national de Strasbourg (TNS), voies d'accès privilégiées aux « grands metteurs en scène " (Katz 2005 ; Thibault 2015). Pour autant, parmi les enquêtés rencontrés, cinq comédiens âgés d'environ 30 ans ont été formés soit dans une école supérieure soit dans la classe libre du cours Florent (cf. encadré sur les caractéristiques sociales des enquêtés). Il est significatif qu'ils aient davantage été employés pour des productions et des organisations théâtrales mieux financées par la puissance publique que leurs collègues autodidactes ou issus de conservatoires municipaux et de cours privés. La trajectoire initiale de ces jeunes comédiens, au sein du réseau des théâtres publics et de compagnies subventionnées, s'inscrit dans un univers professionnel plus légitime et sélectif que celui de leurs collègues travaillant davantage pour des compagnies peu subventionnées, pour le café-théâtre ou pour le théâtre privé.

Les débuts de leur parcours illustrent ainsi le bénéfice que de jeunes comédiens retirent de la fréquentation d'une école d'art dramatique supérieure pour pénétrer le champ théâtral (CESTA 2005 ; Thibault 2015). Dans un premier temps, en effet, leurs expériences professionnelles commencent favorablement grâce au parrainage d'enseignants également actifs dans le réseau des CDN. Cependant, le tissu nationaux and CDNs, or-for those least integrated into the labour market-from government subsidies. In this light, they rightly hold their initial training programmes as the main reason for their exclusion or their imperfect integration into the "subsidized theatre family." None of the interviewees is employed at a théâtre national, nor had any attended the Conservatoire national supérieur d'art dramatique (CNSAD) in Paris or the École supérieure d'art dramatique of the Théâtre national de Strasbourg (TNS) - which are considered to be the privileged pathways to the "greatest directors" (Katz 2005; Thibault 2015). But, interestingly, among the actors who were interviewed, five aged around thirty who were trained at a higher institution or in the Cours Florent Classe libre (see "Characteristics of the Actors Interviewed" box) were employed in well-financed theatre productions and organizations more often than their colleagues who were selftaught or trained in municipal conservatories and on private courses. Within the public theatre and subsidized companies network, their initial career paths fit into a more legitimate and selective professional universe than that of their colleagues working for minimally subsidized companies, café-theatres, or private theatres.

Their previous career paths illustrate the advantage in entering the field that young actors receive from attending a higher institution (CESTA 2005; Thibault 2015). First of all, their professional experiences begin favourably thanks to the support of teachers who are also active in the CDN network. However, the professional fabric construed in these schools appears to be more fragile than that available to former 
professionnel façonné dans ces écoles apparaît plus fragile que celui qui s'offre aux anciens élèves des deux seuls établissements nationaux sous la tutelle du ministère de la Culture (CNSAD et école du TNS), d'autant que ces derniers sont soutenus par l'État après leur formation ${ }^{15}$. Ainsi, après un début prometteur, les comédiens enquêtés souffrent d'un essoufflement graduel de leur progression professionnelle. Leurs carrières, qui se sont développées localement, peinent, après plusieurs années, à rayonner nationalement, alors que dans le même temps, les CDN de province s'ouvrent aux artistes issus des réseaux nationaux. Tous s'interrogent sur le choix entre un déménagement à Paris, dans l'objectif incertain d'une densification de leurs relations professionnelles, et la poursuite d'une activité en province en composant avec les conditions salariales des compagnies locales, moins avantageuses, voire précaires. Certains hésitent également à abandonner l'activité de comédien. Ce découragement est évidemment renforcé par la perte des droits à l'indemnisation, vécue comme un échec.

15 Depuis 1971, le Jeune théâtre national, dispositif dédié à l'insertion professionnelle des jeunes comédiens issus du CNSAD et de l'école du TNS, permet à ces derniers de bénéficier pendant trois ans après leur formation d'un soutien financier pour le paiement de leurs salaires dans le cadre de projets professionnels sélectionnés. Depuis quelques années, les comédiens issus des autres écoles supérieures (qui, elles, ne relèvent pas de la tutelle du ministère de la Culture) bénéficient de dispositifs comparables, bien qu'excentrés par rapport au JTN parisien. Les comédiens interrogés dans le cadre de cette enquête n'ont pas pu en bénéficier, ces dispositifs étant encore en gestation après leur sortie de formation. De ce fait, au cours des entretiens, ils dénoncent comme déloyale la concurrence des anciens élèves du CNSAD et du TNS appuyés par le JTN. students of the only two national institutions which are run by the Ministry of Culture (the CNSAD and the TNS), insofar as the latter receive government subsidies after their training ${ }^{15}$. Thus, after a promising start, the actors interviewed suffered a gradual slowing of their career progression. After a few years - their careers having taken off in the local areastruggled to evolve to the national level. While, at the same time, provincial CDNs have increasingly welcomed actors from the prestigious national schools. This leaves them faced with the difficult choice between moving to Pariswith the uncertain objective of developing new professional relationships - and pursuing their professional activity in the provinces with local theatre groups despite less advantageous, or even precarious, financial conditions. Some even think about giving up the acting profession. This despondency is obviously fuelled by the loss of their unemployment benefits, which is experienced as a failure.

15 Since 1971, the Jeune théâtre national (JTN), a scheme which gives caree support to CNSAD and TNS alumni, has offered young actors funding for selected professional projects for three years following their professional training. In recent years, actors from other higher institutions (not under the supervision of the Ministry of Culture) also started to receive similar funding opportunities, although those remain more peripheral, since they take place outside of Paris, unlike the JTN. In any case, the actors interviewed for this survey were unable to benefit from such opportunities, which were still in negotiation when they finished their training. As a result, during the interviews, they speak about the unfair competition from CNSAD and TNS alumni, supported by the JTN system. 


\section{Les conditions « normales » du métier : des modalités de travail réservées à une élite ?}

C'est que travailler avec les « petites compagnies qui se paient comme elles le peuvent avec les représentations» équivaut à "la découverte d'un monde ", pour reprendre les mots d'une comédienne qui fait partie de ces jeunes artistes accoutumés aux conditions d'emploi des productions soutenues par les théâtres publics ${ }^{16}$. Celle-ci n'avait jamais répété sans être rémunérée jusque-là. Son cas montre que les « dispositions au sacrifice et au don de soi » varient selon les ressources dont disposent les acteurs et, davantage ici, selon les contextes professionnels qu'ils sont amenés à expérimenter (Sorignet 2014). Comme l'écrit Serge Proust, " le pôle le plus professionnalisé et rationalisé du théâtre public (celui des théâtres nationaux et centres dramatiques nationaux) » pourrait bien être ainsi le terrain d'une « mise à l'épreuve » de l'idéal de la troupe et des valeurs d'abnégation qu'il suppose (Proust 2003 : 110-111). Est-ce à dire que la distance prise avec l'ascèse artiste est uniquement le propre d'une minorité formée en école supérieure ? Après avoir connu des conditions de travail « privilégiées », ces jeunes comédiens expérimenteraient le décalage entre une conception « élitiste » du métier et les conditions ordinaires de son exercice, définies par la « débrouille » et la précarité de l'emploi ${ }^{17}$. Sans en déduire une relation mécanique, on peut établir une correspondance entre les trajectoires des

16 Céline B., voir infra.

17 Je cite ici un responsable de structure spécialisée dans les « bilan et accompagnement professionnels » de comédiens qui décrit les anciens élèves d'écoles supérieures selon ces termes.

\section{Are the "normal" working conditions of the profession reserved for an elite?}

Working with "smaller companies which are barely able to support themselves financially via their productions" is equivalent to "discovering a new world," in the words of a young actress accustomed to employment conditions in public theatres ${ }^{16}$. She had never rehearsed without being paid until then. Her case shows that "predispositions towards self-sacrifice" vary according to the resources available to actors and even more so according to the professional contexts that they end up experiencing (Sorignet 2014). As Serge Proust writes, "the most professional and rationalised division of public theatre (i.e., théâtres nationaux and CDNs)" could thus be a "testbed" for the ideal of the theatre troop, and for the values of self-denial that this supposes (Proust 2003: 110-111). Is the shift away from artistic asceticism then only characteristic, of a minority of artists trained in higher institutions? Having experienced "preferable" working conditions, these young actors become acquainted with the gap between the "elitist" perception of the job and the ordinary conditions of the profession in practice, defined by an attitude of "getting by," and employment instability of the profession ${ }^{17}$. Without attempting to impose a mechanical relationship, we can establish a link between respondents' career paths which fall within those structures most respectful of conventional standards, and their critique of working conditions in smaller companies, or even their identification with the wage system

16 Céline B., see below.

17 I quote a manager specialized in "professional coaching" for actors, who described former students of higher institutions under these terms. 
enquêtés au sein des structures les plus respectueuses des normes conventionnelles et leur critique des conditions de travail au sein des petites compagnies, voire leur identification au salariat et à ses droits. À l'inverse, les individus étrangers au travail en CDN et en théâtres institutionnels identifient plus rarement, et donc dénoncent moins en tant que telles, les entorses aux normes salariales. II est ainsi significatif de constater que l'éthique du désintéressement est d'autant plus marquée chez les comédiens situés sur les segments les moins stabilisés du marché de l'emploi théâtral. C'est en effet chez les individus les plus familiarisés avec la précarité professionnelle que l'on trouve davantage les conceptions éthiques qui la justifient, autrement dit un « principe de rationalisation de l'engagement permettant de faire face [...]

à l'incertitude de la vie d'artiste » (Laillier 2011 : 494).

Cette interprétation vaut également pour la position intermédiaire des comédiens plus âgés, dont la période d'initiation professionnelle, au sein de compagnies, court des années 1980 à 1990 (période décrite par certains d'entre eux comme «l'âge d'or des années Lang ${ }^{18}$ »). Socialisés à un " idéal de la troupe » (Proust 2003) - cependant supporté par des conditions d'accès à l'indemnisation chômage plus favorables avant la réforme de 2003 - ils tolèrent encore d'être mis à contribution gratuitement sur des projets collectifs, davantage que leurs collègues plus formés. Mais c'est aussi souvent faute de mieux. Quand ils ont eu la possibilité d'expérimenter le confort des institutions publiques, c'est ce

18 L'expression « Les années Lang » provient du nom du ministre de la Culture, Jack Lang, en poste entre 1981 et 1986, puis entre 1988 et 1992. and its rights. On the other hand, individuals who have never worked at a CDN or other institutional theatres are more rarely capable of identifying infringements of salary standards, and therefore denounce it less often as such. It is therefore significant that the stance of selflessness is an even more noticeable trait amongst actors at the less stable end of the theatre employment market. Individuals who are more familiar with professional insecurity are more likely to find ethical justifications for their situation; in other words, they find a "rational principle to cope [...] with the uncertainty of life as an artist" (Laillier 2011: 494).

This interpretation also applies to the transitional position of older actors, whose period of professional initiation within theatre companies took place in the 1980s and 1990s (the "golden age of the Lang years ${ }^{18}$ ). This group appears to tolerate working for free on collective projects more than colleagues who have completed more recognized and longer periods of training: but it is also often for want of anything better. When they had the possibility of trying out the security of working for a public institution, they determined the situation

18 The expression the "Lang years" comes from the name of Culture minister Jack Lang, who held this post between 1981 and 1986, and then between 1988 and 1992. This period saw easier access to unemployment benefits and considerable investment into the arts, and was halted by the application of the 2003 reform. 
dernier espace professionnel qui, pourtant souvent désigné comme privilégié, leur apparaît pleinement respectueux de

l'exercice « normal » du métier :

" Là pour le coup, ça doit être que dans le théâtre subventionné [l'enquêtée fait référence à son expérience dans un grand théâtre municipal parisien] que l'on retrouve des conditions qui devraient être normales. Parce que les répétitions, c'est quand même pas le moindre dans notre métier. Et je pense maintenant qu'il $y$ a guère que le théâtre subventionné qui peut se permettre de payer confortablement et de déclarer. Ça les répétitions, c'est un gros problème. Ça reste un gros problème. ” (Sophie J., 50 ans, comédienne, formée en conservatoire municipal de province et cours privé parisien, est sur le point de recouvrer ses droits à l'indemnisation chômage en mai 2012 après une période d'exclusion de six mois, vit à Paris.)

C'est qu'en réalité, « travailler dans le subventionné, c'est pas juste une histoire d'argent » pour reprendre les termes de sa collègue de la même génération, qui évoque alors sa seule expérience de création produite par un CDN dans les années 1990. Si son métier semble pour elle pleinement reconnu dans les institutions publiques, c'est d'abord parce que le temps de la création - c'est-à-dire, notamment, des répétitions - y est rémunéré. Mais c'est aussi parce qu'y règne une division claire du travail entre les différents métiers impliqués dans la création :

«C'est un confort de travailler avec les techniciens, ce que moi j'aime beaucoup. Parce que le spectacle nécessitait qu'il y ait des réglages qui ne pouvaient pas s'enregistrer as completely respectful of "normal" working conditions, despite being often seen as privileged.

"In this case [reference made to experience in a large municipal Parisian theatre], we find what should be categorized as normal working conditions only in subsidized theatres. Because rehearsals aren't exactly the least important part of our job. And I think that now only subsidized theatres can afford to pay and declare actors comfortably. Rehearsals are a huge problem. They are still a huge problem." (Sophie J., 50 years old, actress, lives in Paris, trained in the municipal conservatory and Parisian private classes. About to regain unemployment rights in May 2012 after a six-month deferral period).

"Working in the subsidized business is not just about the money," to quote one of her co-workers of the same generation, who then referred to her sole experience of a creative production by a CDN in the 1990s. For this colleague, full recognition of her work in public institutions specifically means being paid for "creative," behind-the-scenes workthat is to say for rehearsals in particular. But this is also because of a clear division of labour between the different jobs involved in this creative work:

"It's great to work with technicians, I really like that. Because the show demanded certain effects that couldn't in fact be pre-recorded. [...] I have very good memories of 
en fait. [...] C'est un très bon souvenir aussi de ce point de vue-là, parce que ça se tricotait vraiment ensemble, entre la technique et l'artistique pour faire avancer le spectacle. D'ailleurs pour moi [...] c'est vraiment un tout. » (Clarisse N., 48 ans, comédienne, formée en cours privé parisien, a connu des périodes d'exclusion de l'indemnisation chômage de plus de six mois consécutifs en 2003 et 2007 [durées exactes non précisées] et d'un mois en janvier 2012, bénéficie de ses droits en janvier 2013, vit à Paris.)

Une nette division du travail entre chaque métier au sein de l'organisation a pour corollaire la possibilité pour l'acteur de mobiliser son savoir-faire spécifique, en interaction avec les compétences de ses collaborateurs. À la dispersion d'énergie que supposent la polyvalence et le brouillage du temps de travail dans une compagnie peu financée, s'oppose la concentration créative que permet le professionnalisme du théâtre institutionnel :

« - Quand on arrive dans un théâtre subventionné, c'est pas le Théâtre des Offices [petit théâtre privé parisien qui loue son espace aux petites compagnies] !

- L'équipement, tout bêtement. Un théâtre spacieux, des loges spacieuses, tout bêtement. On a un régisseur qui vous donne le top une demi-heure avant, un quart d'heure avant. On a juste à penser au jeu quoi. II y a les costumes, une costumière, une habilleuse [...]. Moi je sortais de la Jonquille [compagnie itinérante] où sur la route, on fait tout. Quand je dis qu'on fait tout : on décharge le camion, on monte le décor. C'est à l'ancienne : Molière. On règle les éclairages, on répète un peu, on joue, on sort de scène, on démonte, on décharge le camion. Et puis comme on est chez l'habitant, on discute un peu avec eux. Parce que it, since between the technical and artistic aspects of the show, it all knitted together really well so that things moved forward. Besides, in my opinion [...] it's really a whole." (Clarisse N., 48 years old, actress, lives in Paris, trained in private Parisian classes. Experienced periods of exclusion from unemployment benefits for more than six consecutive months in 2003 and 2007 [exact dates not specified], and one month in January 2012 . She regained her rights in January 2013.)

The consequence of a clear division of tasks between each role within an organisation is that actors can engage with their specific expertise in combination with the skills of their coworkers'. The creative focus brought by the professionalism of institutional theatre contrasts with the dispersion of energy required by the versatility and blurring of roles in a poorly funded company:

"- When you join a subsidized theatre, it's not the Théâtre des Offices! [A small, private Parisian theatre which rents out space to smaller groups.] - Meaning what, exactly?-Facilities, quite simply. A spacious theatre, spacious dressing rooms: that's what I mean. We've got a stage manager who gives us a pip half an hour before, fifteen minutes before. All we've got to think about is acting, that's it. There's a costume designer and a dresser who potentially take care of the costumes [...] I myself came from the Jonquille [a travelling theatre company], where we did everything on the road. When I say that we did everything-we unloaded the truck and prepared the set. Like in the old days of Molière. We adjusted the lighting, rehearsed a bit, performed, left the stage, took everything apart, and loaded the truck again. And since we'd be staying at someone's house, we'd 
pour eux à chaque fois c'est une fête. Même si pour nous, à chaque fois on est fatigués. Donc il s'agit pas de leur gâcher leur plaisir. Là, c'est l'opposé absolu. On a juste à jouer. » (Sophie J., comédienne, voir supra.)

Les faibles capacités financières des organisations pour lesquelles travaillent les comédiens interrogés supposent de cesderniersunsurcroîtd'effortpourpallierles défautsmatériels. Qu'il s'agisse des répétitions à préparer à son domicile, des opérations techniques à ajuster faute de techniciens ou des costumes à arranger, la polyvalence, synonyme d'esprit de troupe et, éventuellement, d'enthousiasme, est aussi souvent décrite comme source d'éparpillement et de fatigue.

\section{Les restrictions matérielles, facteur d'altération de la qualité du travail}

Selon les réseaux professionnels (dotés ou non) dans lesquels il se situe, un comédien connaît des conditions de travail (polyvalence ou division stricte du travail entre les différents métiers) et de rémunération (prise en compte ou non du temps de création) extrêmement différentes ; mais la variabilité de cette situation détermine tout autant le contenu de l'activité. Ce constat est d'autant plus évident dans le cas de cet acteur comique habitué aux salles privées lyonnaises ${ }^{19}$, qui travaille toujours ses répétitions sans salaire et doit adapter ses spectacles à une économie de moyens : deux acteurs engagés au maximum. Non seulement cet acteur souffre

1940 ans, autodidacte, recouvre ses droits à l'indemnisation en mars 2013 après quatre mois d'exclusion de l'indemnisation chômage, a également été exclu de ses droits durant quatre ans entre 1997 et 2002, vit en région lyonnaise. have a little chat with them. It was a little party for them each time. We'd be so tired, but it was a case of not spoiling their fun. Now it's the complete opposite. We've just got to act." (Sophie J., actress, see above.)

The lack of financial resources of the organizations the interviewees work for requires an increased effort in order to overcome the material issues they face. From organizing rehearsals at home, through technical operations that need to be taken care of because of a lack of technicians, to costumes that need adjusting-versatility at work, although synonymous with troop team spirit and enthusiasm, is often described as a source of dispersion and fatigue.

\section{Material restrictions, a degrading factor in quality of work}

An actor's work and pay conditions (that is, whether they work in versatile roles or within a strict division of labour, and whether or not they are paid for behind-the-scenes work) vary greatly depending on the resourcing of their professional networks; and the variability of this situation equally determines the content of their professional activity. This observation is even more evident in the case of a comic actor who is used to working in private halls in Lyon ${ }^{19}$, who still rehearses without being paid, and adapts his performances to his budget: with a maximum of two hired actors. Not only does he suffer from the flexibility imposed on him by this arrangement, but he is

19 Forty years old, self-taught, lives in the region of Lyon. She was excluded from unemployment benefits for four months, and was accepted in March 2013. The same occurred between 1997 and 2002. 
de la polyvalence de jeu que ce format lui impose, mais il est convaincu que, dans ces conditions, il ne pourra jamais accéder aux « textes de qualité » à l'origine de sa vocation (Cyrano, Shakespeare), à moins de pouvoir un jour franchir les « murs » qui le séparent du TNP de Villeurbanne (CDN) ou du théâtre des Célestins (théâtre municipal lyonnais). Le raisonnement vaut aussi dans les régions moins mercantiles de la profession. En effet, les petites compagnies peu subventionnées qui entreprennent de monter Molière ou Lorca sans trop de financements n'offrent guère plus de garanties de « qualité » à leurs comédiens. Faute de pouvoir rémunérer suffisamment de répétitions, la surcharge de travail et le manque d'élaboration collective ont des incidences directes sur le contenu de la pratique artistique :

«Moi je sais que < pour jouer Henriette dans> les Femmes savantes [...] chez Colombine [nom de la compagnie], j'ai dû avoir six répétitions. C'était vertigineux, parce que c'est un rôle énorme et j'étais totalement paniquée la première fois que je l'ai joué. Six répétitions, c'est très peu. [...]. Ça fait que moi, j'ai énormément travaillé chez moi, comme le font les musiciens ou les chanteurs [...], sauf que, pour le théâtre, rien ne remplace les répétitions ensemble. Donc il y a une partie du théâtre que l'on peut faire tout seul. Mais il y a un moment où on a besoin des autres. Et de ce point de vue là, ça influe sur la qualité, parce qu'il y a une partie du travail que l'on peut pas faire tout seul. Et en plus travailler comme ça dans l'urgence, la fatigue, etc. Je pense que nerveusement cela amène quelque chose qui n'est pas bon pour la sérénité du spectacle et de l'ensemble. Du coup ça génère un stress qui, évidemment, n'est pas bon pour la qualité du spectacle. On peut pas tout pallier. » (Sophie J., comédienne, voir supra.) also convinced that, in these circumstances, he will never have the chance to work with the "quality texts" that inspired his vocation (Cyrano de Bergerac, Shakespeare, etc.) unless one day he is able to breach the "walls" that separate him from the TNP in Villeurbanne (CDN) or the Theatre des Célestins (Lyon's municipal theatre). But this reasoning also goes for less profit-seeking areas in the profession. Small subsidized companies which take on Molière or Lorca without enough funding offer barely any guarantee of "quality" to their actors. Since they are unable to sufficiently pay the actors for rehearsals, the work overload and the lack of collective development have a direct impact on the artistic practice produced:

"I know that for Les Femmes Savantes, playing Henriette at Colombine [name of the theatre company], I had about six rehearsals. It was dizzying, because it's such a huge role and I was totally freaked out the first time I played it. Six rehearsals is very little [...]. This meant I worked a lot at home, like musicians or singers do [...] Except that nothing can replace rehearsing together in the theatre. There comes a point when you need to work with others. And that's where it affects the quality, because there is a part of the job that you just cannot do alone. What's more, working under pressure, dealing with fatigue, etc. - I think that brings something that's not necessarily good for the serenity of the performance and the group. So, it generates stress, which, of course, is not good for the quality of the performance. We can't cover up everything." (Sophie J., actress, see above.) 
Les discours convenus sur les professions artistiques conçoivent l'amour de l'art ou le génie comme des antidotes à toute forme de découragement. II en va de même lorsque la sociologie reconduit la notion de «talent ». Comme l'a analysé Manuel Schotté, une telle notion pousse dans un même élan à envisager la « motivation intrinsèque » ou "l'excès de confiance et d'optimisme » comme des variables déterminantes dans les inégalités de réussite. En réalité, les qualités artistiques ne sont pas « déjà-là », attendant un terrain propice à leur floraison (Schotté 2013 ; voir aussi Jeanpierre 2012). En l'occurrence, le champ d'action des artistes, et donc, la construction, par eux-mêmes, de la qualité de leurs réalisations, sont grandement déterminés par les conditions matérielles de leur pratique, inégalement distribuées entre les différents segments du marché du travail. Or, c'est bien de cela que dépend la « motivation intrinsèque »:

« Si on est payé pour répéter, on ne fait que ça. Si on n'est pas payé, ben, on est obligé d'aller bosser ailleurs. C'est aussi bête que ça. " (Clarisse N., comédienne, voir supra.)

Ainsi, la présence d'un acteur en répétition se conçoit autant sur un plan physique que mental. La fatigue engendrée par la gratuité des investissements, qui occasionne déjà une privation de revenu, a aussi potentiellement des effets négatifs sur l'énergie mobilisable. Sans se prendre personnellement en exemple, les individus interrogés peuvent au moins en faire l'observation pour leurs collègues :
The formulaic discourse on artistic professions shows a love of art or genius as an antidote to any form of discouragement. This also applies to sociology's extension of the notion of "talent." As Manuel Schotté notes, such a notion similarly asks us to consider the "intrinsic motivation" or the "excess of trust and optimism" as determining factors in the inequality of success. In reality, artistic qualities are not "already there," waiting for fertile ground to grow (Schotté 2013; see also Jeanpierre 2012). As it happens, artists' sphere of operation (and therefore, their own construction of the quality of their achievements) is largely determined by the material conditions of their creative practice, unevenly distributed throughout different segments of the employment market. Their "intrinsic motivation" thus depends on this:

"If we get paid to rehearse, we do that and only that. If we aren't paid, well, that means we have to find work elsewhere. It's as simple as that." (Clarisse N., actress, see above.)

Therefore, an actor's presence in rehearsals can be understood on both the physical and the mental level. Fatigue caused by unpaid work, which already causes a loss of income, can also potentially negatively affect the actor's available physical energy. Without taking themselves as an example, the individuals interviewed can at least observe this in their colleagues: 
«lls[lethéâtre-salleprivéeparisienne]paientuntechnicien. Un technicien lumière, tout ça. Et s'il ne fait pas son boulot, c'est nous qui nous tapons de porter tous les accessoires, etc. En plus, mes deux camarades, c'est eux qui font l'animation scolaire. Ils sont sur les genoux. [...] Ils le disent d'ailleurs. "On n'est pas allés à fond." [...] Toute la fatigue engendrée nuisait à leur concentration avant d'être sur scène. " (Amélie S., 57 ans, comédienne, formée en cours privé parisien, a été exclue à plusieurs reprises de l'indemnisation chômage plus de six mois [périodes exactes non précisées], vit à Paris.)

$\mathrm{Au}$ fil des questions sur les conditions effectives de leur travail, certains enquêtés en arrivent à prendre leur distance avec l'« injonction au bonheur » dont leur métier fait l'objet. Ils rompent alors avec l'illusio, leur « talent » ne leur permettant pas de déjouer les difficultés matérielles (Sinigaglia 2013). Dans ces cas, la perception de leur travail comme altéré et inaccompli les conduit à remettre en cause leur identité professionnelle d'acteur. Faute de pouvoir mesurer leurs aptitudes dans les conditions de travail les plus régulées, certains se comparent même aux artistes amateurs rencontrés

sur certaines scènes :

" "Semi-professionnelle" : objectivement si, par exemple, je joue sur un spectacle et que j'accepte de ne pas être payée sur les répétitions, et que j'accepte d'être payée a minima pour les représentations, 70 euros le cachet, c'est bien évident que je ne gagne pas ma vie avec. [...] Je pense qu'il y a vraiment des amateurs qui ne font pas si mal leur boulot que ça. Je pense qu'il y a des professionnels qui, à force de courir à droite à gauche pour gagner leur vie, ou autrement, produisent des choses de qualité moindre, à force de rogner sur le temps de répétition, sur
They [a Parisian private theatre] pay a technician. A lighting technician, and all that. And if he doesn't do his job, it's us who have to pick up the slack and carry all the accessories, etc. Besides it's my two colleagues who do performances in schools. They are on their knees. [...] They say it too. 'We didn't do a good job.' [...] Their tiredness affected their concentration before going on stage." (Amélie S., 57 years old, lives in Paris, actress, trained in private Parisian classes. She has been excluded from unemployment benefits on numerous occasions for more than six months [exact dates unspecified].)

During questions on the reality of their working conditions, some actors even end up distancing themselves from the "prescribed happiness" to which their profession is subjected. They break with their illusio, since they cannot surmount material deprivation by way of their "talent" (Sinigaglia 2013). In such cases, the perception of their work as altered and unaccomplished calls into question their professional identity as actors. Because they are unable to measure their aptitude within more controlled working conditions, some even compare themselves to the amateur actors they end up working with in certain theatres:

“'Semi-professional'-objectively, if for example I'm in a show and agree not to be paid for rehearsals and to be paid the minimum wage for performances, a 70-euro fee, it's pretty obvious that I can't make a living on that. [...] I think that there really are amateurs who are not at all bad at their job. I think there are professionals who perform less well because they are running around trying to earn a living. Due to cutbacks on rehearsals, and performance conditions. Yes, these are the conditions: 'Ok, we're going to do this, but come on, this isn't serious at all!' [...] When a programmer 
les conditions de spectacle. [...] $<$ On se dit> "Ok, on va le faire, mais enfin, c'est pas sérieux tout ça." [silence] [...] Quand un programmateur met 200 personnes dans une pièce [i.e. dans le public] alors qu'on avait bien dit que c'était un spectacle pour 50 personnes. Je me retrouve dans des conditions où, de fait, je suis mise devant le fait accompli, le spectacle se joue et... ça ne correspond pas aux dimensions du spectacle. Et voilà : on fait de la merde. »

(Jeanne C., comédienne, voir supra.)

L'observation de cette enquêtée concentre à elle seule les contradictions qui traversent le marché du travail des comédiens et les représentations communes qui les réactivent. L'art, s'interroge-t-elle, relève-t-il effectivement de conditions de travail socialement déterminées ? La prestation d'un amateur ne peut-elle parfois surpasser celle d'un professionnel déclaré ? Mais c'est finalement parce qu'ils sont arrimés aux mêmes situations de (quasi-)bénévolat, que l'un ne s'en sort « pas si mal », quand l'autre rogne sur la «qualité » de son travail. En définitive, c'est l'amateurisme des conditions d'emploi (« c'est pas sérieux tout ça!») qui, méconnaissant à la fois la valeur salariale du comédien et les exigences techniques minimales de son métier, oblige ce dernier à se départir lui-même de tout professionnalisme.

\section{Les activités « limitrophes » : détournement technique et marginalisation professionnelle}

«Perdre le contact avec le plateau »

Le sentiment, exprimé par les intéressés, d'une forme d'éloignement de son métier ne se résume donc pas au moment brutal où, perdant la source majeure de revenus que puts two hundred people in the audience when it was clear that it was a performance for fifty people. I find myself in situations where I am faced with the fait accompli, we're in the middle of the show and [...] it doesn't fit with the scope of the performance. So we end up producing something crap." (Jeanne C., actress, see above.)

This actress's observation contains the contradictions prevalent in the acting sector and the common representations that trigger them. Is art indeed dependent on socially determined working conditions? Can an amateur actor's performance surpass that of a declared professional? It is ultimately because they are bound to the same non-regulated situations that one is "not at all bad" while the other is cutting corners on the "quality" of his or her work. Ultimately, it is amateur job conditions ('this isn't serious at all!') that force actors away from any sense of professionalism: conditions that are ignorant of both the financial value of actors and the minimal technical requirements of the job.

\section{Adjacent activities: technical diversion and professional marginalization}

\section{"Losing touch with the stage"}

The feeling of detachment from their trade expressed by some of the actors concerned does not boil down to the sudden moment when the loss of unemployment benefits, a 
représente l'indemnisation chômage, s'éteint le dernier signe de leur identité professionnelle. En réalité, leur désaffiliation professionnelle commence en amont. Elle se traduit par l'expérience d'emplois peu valorisés où ils constatent l'altération de leur pratique artistique. Cette altération est encore vécue dans le recours à diverses occupations limitrophes au métier traditionnel de comédien, occupations qui ne lui sont pas rattachées sans problème de définition.

L'homologation d'un certain nombre de ces activités par l'annexe 10 de l'assurance chômage, comme relevant du métier d'« artiste du spectacle », n'empêche pas certains enquêtés de les vivre comme un détournement de leurs aspirations initiales. Le sentiment d'aliénation dont témoigne la plupart des individus interrogés ne relève donc pas de l'exercice de " petits boulots » étrangers au savoir-faire de comédien, c'est-à-dire d'une forme de polyactivité ${ }^{20}$ non souhaitée. C'est au contraire la ressemblance de ces emplois de subsistance avec leur pratique artistique qui génère un sentiment critique. C'est pourquoi certains se distancient d'une telle forme de pluriactivité et consacrent leur temps à un travail alimentaire clairement défini comme tel.

On ne peut cependant mettre toutes ces activités limitrophes sur le même plan, ne serait-ce que du point de vue des compétences qu'elles requièrent. Certaines d'entre elles sont

20 Je reprends ici la distinction opérée par Janine Rannou et lonela Roharik entre polyactivité - le fait de se consacrer à plusieurs activités relevant de champs professionnels distincts - et pluriactivité - le fait de se consacrer à plusieurs activités relevant d'un même champ professionnel (Rannou \& Roharik 2006) major source of income, extinguishes the last sign of their professional identity. In fact, their professional disaffiliation begins well before. It manifests itself in undervalued jobs in which they notice the degradation in their artistic practice. This can be seen in the resort to jobs that are loosely related to traditional acting roles, but which cannot be said to be unconnected to the profession without creating problems with its definition.

The approval of several of these activities in appendix 10 of unemployment insurance as being related to the "performance artist" trade does not prevent some interviewees from viewing them as a diversion from their original aspirations. The alienation described by most of the interviewees is therefore not due to doing "odd jobs" that are far removed from the typical skillset of the actor, that is to say, a sort of unintended professional poly-activity ${ }^{20}$. It is, on the contrary, the resemblance of such jobs that pay the bills to their artistic practice which instigates these actors' feel critical towards. It is for this reason that some distance themselves from such a form of "pluriactivity," and devote their time to bread-andbutter work that is clearly defined as such.

We cannot, however, put these adjacent activities on an equal footing, if only because of the difference in skills they require. Some of these activities are described as requiring

20 I refer here to the distinction made by Janine Rannou and Ionela Roharik between professional poly-activity (focusing on several jobs from separate professional fields) and pluriactivity (focusing on several activities within the same professional field) (Rannou \& Roharik 2006). 
décrites comme n'exigeant aucune expérience ni initiation à l'art du comédien : faire de la figuration audiovisuelle, être employé comme statue vivante au Musée Grévin, incarner des personnages costumés dans des parcs d'attraction ou se déguiser en père Noël pour les grands magasins. D'autres paraissent nécessiter des compétences d'artistes, mais mobilisées de façon routinière : égayer les visites du Musée des arts forains, effectuer des numéros de clown à Marineland, animer des goûters pour enfants ou travailler dans l'événementiel. Enfin, certaines supposent l'exercice de techniques proprement théâtrales, mais déviées de leur but initial. C'est le cas de la formation ou de l'enseignement, parfois sous forme d'intervention socio-culturelle auprès de publics dits "en difficulté », ou de la représentation théâtralisée de problématiques managériales en entreprise. Parce qu'elles occasionnent un important sentiment de dépréciation personnelle, les activités décrites comme les moins qualifiées sont unanimement décriées. En revanche, la formation et l'animation socio-culturelle, et davantage encore le théâtre en entreprise, suscitent des avis plus positifs.

Ainsi, les enquêtés qui se consacrent aux activités de formation et d'animation défendent la transmission de savoirs spécifiques de comédien comme « relevant du métier », et déplorent, à ce titre, le fait qu'il soit si difficile de les faire reconnaître dans le cadre de l'annexe 10 de l'assurance chômage $^{21}$. Ils concèdent cependant que ces savoirs sont

21 Depuis la réforme de 2003, la comptabilisation des activités d'enseignement au titre de l'indemnisation des artistes du spectacle est limitée à $55 \mathrm{~h}$ et à $90 \mathrm{~h}$ pour les plus de 50 ans (le niveau du plafond devrait être cependant no experience or previous entry into the art of acting: being a film extra, being employed as a living statue at the Grevin Museum, playing costumed roles in amusement parks, or dressing up as Santa Claus for department stores. Others appear to require artistic skills, but in a rather routine capacity: providing entertainment at Paris's fairground museum, performing as a clown at Marineland, performing at children's after-school snack times, or working a management event. Finally, some activities require techniques that are entirely theatrical, but which depart from their original purpose. The same goes for teaching, sometimes taking the form of sociocultural intervention for "disadvantaged" publics, or dramatic representations of managerial issues in businesses (corporate roleplay). Various subjective relationships to these different jobs ensue. The activities described as needing the least skills are unanimously criticized for the sense of personal depreciation they cause. On the other hand, teaching and sociocultural work-and corporate roleplay even more sostir up more positive reactions.

Therefore, the interviewees who have dedicated themselves to teaching or working as activity group leaders defend the transmission of specific acting skills as "part of the job." They therefore deplore the fact that it is so difficult for such activity to count under appendix 10 of the unemployment insurance regulation ${ }^{21}$. They concede, however, that these skills have

21 Since the 2003 reform, recognition of teaching activities with regards to unemployment compensation for "intermittent performers" is limited to 55 or 90 hours for $50+$ year olds (the upper limit was, however, raised from 
détournés de leurs finalités créatives vers des usages sociaux ordinaires (comportements professionnels ou éducation civique) et justifient à chaque fois de tels engagements par des motivations pécuniaires. II s'agit explicitement de pallier la baisse d'activité et de pouvoir cotiser à l'assurance chômage. C'est ce que dénoncent d'autres enquêtés, comme Jean B. ${ }^{22}$, acteur, habitué au travail en compagnie, qui, s'estimant « comédien, pas prof », y voit un expédient à la « [perte de] contact avec le plateau ».

Le théâtre en entreprise est plus ouvertement utilitaire que l'engagement dans la formation ou l'animation. Pour les comédiens qui y sont employés, cette activité s'apparente à une forme « d'art mercenaire », très éloigné des exigences de « l'art pur » (Mauger 2006) auquel ils préféreraient dédier leur temps. Mais le fait qu'ils ne s'arrêtent pas à ces caractéristiques négatives est significatif de leur conception artisanale du métier de comédien à laquelle, non seulement ceux qui pratiquent le théâtre en entreprise, mais les enquêtés dans leur ensemble, sont attachés. Les contraintes mercantiles de ce type de production ne concernent en effet que le contenu des scénarios que les acteurs engagés doivent élaborer

relevé à partir du 1er août 2016 à 70 heures et à 120 heures pour les plus de 50 ans en application de l'accord du 28 avril 2016 et de son avenant du 23 mai 2016). Les interventions socio-culturelles sont quant à elles rattachées à un spectacle, défini par la représentation de l'artiste devant un public, auquel le travail est donc censé aboutir. Ce critère imprécis fait l'objet de multiples détournements, dont certains enquêtés témoignent pour leur compte ou celui de collègues.

2254 ans, autodidacte, bénéficie de ses droits à l'indemnisation en mai 2012 « a connu plusieurs périodes de creux » dont une de six mois en 2008, vit en région parisienne. been diverted from their creative ends towards more ordinary social purposes (professional behaviour or civic education), and justify all such commitments by way of financial motives. It is a case of making up for a decline in activity and being able to contribute to unemployment insurance. It is this that some interviewees object to. Jean B. ${ }^{22}$, an actor used to working with subsidized theatre companies, considers himself to be an "actor, not a teacher," - a role he sees as a route to "[losing] touch with the stage."

Corporate roleplay work is more openly utilitarian than involvement in teaching or working as an activity group leader. For those who are employed in this area, it is similar to a kind of "mercenary art," far from the requirements of "pure art" to which they would prefer to dedicate their time (Mauger 2006). But the fact that the interviewees do not focus on these negative features is therefore significant. Their statements reveal the "artisanal" conception of the acting profession to which not only those employed in this area, but also the interviewees in general are attached. The mercenary pressure in fact only applies in this kind of production to the scenarios which the actors who have been hired must act out, since they are required to stage managerial concerns as

1 August 2016 to $70-120$ hours for the over 50 s in view of the agreement of 28 April 2016 and its endorsement on 23 May 2016). The sociocultural interventions must be linked to a show, which is defined as the intended goal of the representation of an artist before an audience. This rule is subject to multiple diversions, to which certain interviewees testify on their behalf or that of their colleagues.

22 Fifty-four years old, self-taught actor, received unemployment compensation in May 2012, has had "several lull periods," one of six months in 2008. Lives in the Paris region. 
(mettre en scène des préoccupations managériales sous la dictée de leurs interlocuteurs). Dans ce cadre, les comédiens restent libres dans la mise en œuvre des techniques de jeu. Ces conditions spécifiques circonscrivent un champ d'action, certes étroit, mais autonome, où exercer leur savoir-faire. Une comédienne, par exemple, compare cette pratique à une "gymnastique » ou " une barre, comme pour les danseurs », qui lui a permis d'entretenir une mémoire et une rapidité réinvesties ailleurs (dans la Commedia dell'arte en l'occurrence). Cet espace de travail est aussi l'occasion d'outrepasser les clivages professionnels et esthétiques, pour partager un artisanat commun entre acteurs (Moulin 1983 ; Perrenoud 2013) sans intervention des metteurs en scène. Dans la mesure aussi où cette activité, au moins pour les comédiens interrogés, leur donne la possibilité de faire reconnaître leurs compétences en leur procurant un salaire satisfaisant, elle apparaît comme une exception à l'ensemble des emplois peu valorisés utilisés pour pallier leur baisse de cotisation à l'assurance chômage.

On voit donc grâce à ce dernier exemple que la valorisation des occupations annexes ou limitrophes par les intéressés eux-mêmes dépend en grande partie du contenu du travail mobilisé. Les comédiens interrogés admettent ou contestent l'assimilation relative de ces activités au " métier » selon la plus ou moins grande dissemblance entre les opérations techniques qu'elles sollicitent et celles requises en situation de jeu «sur le plateau ${ }^{23} »$. Certes, le travail de définition,

23 Sur la référence au plateau de théâtre comme critère du travail valorisé, voir aussi Rolle \& Moeschler 2014 dictated to them. These restricted conditions define a narrow but nevertheless independent scope within which to employ their skills. One actress, for example, compares this practice to "doing exercises" or "a dancer's bar," which enabled her to develop her memory and speed, which she later reinvested elsewhere (in this case at the Commedia dell'arte). This workspace is also an opportunity to move beyond professional and aesthetic divides and, moreover, to share a common craft amongst actors without intervention from a director (Moulin 1983; Perrenoud 2013). Insofar as this type of activity-at least for the actors interviewed here-gives value to their skills and provides them with a satisfactory salary, it appears to be an exception amongst most undervalued jobs used by actors to compensate for the decrease in unemployment benefits.

We can therefore see, thanks to this last example, that the value given to additional or related jobs by actors depends largely on the content of the work assigned. Our interview respondents accept or reject the relative assimilation of these activities to the profession depending on the degree of similarity between the technical operations the activities solicit and those required by acting "on the stage ${ }^{23}$." Indeed, the categories of unemployment insurance contradict this

23 Regarding the reference to the theatre stage as a criterium for valued work, see also Rolle \& Moeschler, 2014. 
par l'assurance chômage, des bornes de l'indemnisation n'est pas sans contredire cette conception restrictive, en admettant dans son champ les activités unanimement jugées comme étrangères au métier de comédien. Dans un contexte de précarité des conditions d'emploi, cette homologation institutionnelle participe d'une redéfinition concurrente du champ professionnel (Bureau \& Shapiro 2009) autour de ce que certains enquêtés désignent sous le vocable d'« intermittence "24. Mais précisément, même dans ce contexte, les comédiens interrogés restent attachés à une conception technique du métier. Celle-ci ne peut être envisagée comme accordée à une simple « construction nominale » de la pluriactivité (Becker 2009) qui séparerait activité légitime (le « métier ») et activités stigmatisées (les activités limitrophes) - à moins de rabattre toute réalité humaine au niveau de ses représentations discursives ${ }^{25}$. En réalité, cette qualification technique du métier relève aussi de processus très pratiques de transmission des savoir-faire théâtraux au sein de structures de formation que la plupart des comédiens ont fréquentées (Menger 1997) ${ }^{26}$. Ce métier

24 Une seule comédienne parmi les interviewés (Christine B., voir supra.) considère résolument ces occupations limitrophes comme relevant de « son métier », en réclamant une extension du domaine des activités prises en compte par l'annexe 10 de l'Unédic. Mais il s'agit avant tout pour elle d'avoir, faute de financement, une autre source de rémunération que son travail théâtral, qui reste clairement le cœur de son activité.

25 Je rejoins ici la critique d'une conception interactionniste des pratiques professionnelles qui refuse de reconnaître à ces dernières « un contenu réel $[. .$.$] , hormis bien sûr au niveau des représentations collectives et des$ croyances »(Champy, $2009: 24)$.

26 C'est aussi dans cette perspective que l'on peut comprendre l'observation de Serge Proust qui remarque que la socialisation scolaire des comédiens, restrictive conception by its own definition of unemployment beneficiaries. In the context of unstable employment conditions, this institutional approval is part of a simultaneous redefinition of the professional field (Bureau \& Shapiro 2009), referred to by some interviewees as intermittence ${ }^{24}$. But even in this context, the interviewed actors remain attached to a technical notion of their trade. This cannot be explained by adherence to a simple "nominal construction" of pluriactivity (Becker 2009), which would separate legitimate activity (their "job") and stigmatized activities (their adjacent activities) unless we reduce the whole of human reality to the level of its discursive representations ${ }^{25}$. This technical qualification of the job is due to the very practical process of the transmission of theatrical expertise within the training institutions that most of the actors have attended (Menger 1997) ${ }^{26}$. This job has an effective content that is continually renewed and rebuilt during the phases of rehearsal and interpretation, and particularly within the most integrated segments of the employment

24 Only one actress amongst those interviewed (Christine B., see above) resolutely lays claim to this categorization of adjacent activities as jobs within her "field," calling for an extension of the field to be considered in the Unédic appendix 10. But it is above all for her a question of having, owing to a lack of funds, another source of income as well as her theatre work, which clearly remains her main activity.

25 This raises the criticism of an interactionist notion of professional practices, which wouldn't be recognized as "real work"-except of course at the level of collective representations and beliefs (Champy 2009: 24).

26 With this in mind, we can consider Serge Proust's observation that socialization that occurs during schools for actors - which is purely theatrical-is unsuited to secondary activities, especially social and cultural activities that are more and more recommended by local financiers of companies (Proust, 2009). 
a un contenu effectif, continuellement reconduit et reconstruit au cours des phases de répétition et d'interprétation, et notamment sur les segments les plus intégrés du marché du travail, vers lesquels les enquêtés restent polarisés ${ }^{27}$.

\section{Marginalité professionnelle et individualisation du travail d'organisation}

Ainsi, ces activités connexes détournent l'art de l'acteur de ses finalités techniques classiques - la représentation artistique. De même, elles sont éloignées des collaborateurs et recruteurs traditionnels des comédiens. Dès lors, les espaces professionnels constitués par ces activités peuvent certes constituer des lieux de sociabilité et d'assistance entre artistes en difficulté (Menger 2011), mais la marginalité professionnelle de ces derniers rend précisément leurs rencontres peu décisives. La figuration audiovisuelle, par exemple, est au centre des réseaux d'entraide de certains des comédiens interrogés, mais assimilés alors à une sorte de « décor vivant » (Sigalo Santos 2014), ils n'accèdent donc pas, par cette voie, aux intermédiaires les plus significatifs. De même, le théâtre en entreprise occasionne de « belles

purement théâtrale, est inadaptée aux activités annexes, en particulie socio-culturelles, de plus en plus prescrites par les financeurs locaux des compagnies (Proust 2009). Sur le contenu technique des enseignements théâtraux et leur relative ressemblance dans trois structures de formation à Paris et Berlin, voir Katz 2008.

27 II est à ce titre significatif que chez les comédiens autodidactes rencontrés, la volonté de se former (notamment grâce aux stages professionnels) ait correspondu autant au désir d'acquérir les savoir-faire traditionnels de l'acteur qu'à la recherche d'une relative stabilité professionnelle au sein du champ théâtral. market, towards which all the actors interviewed remain polarized $^{27}$.

\section{Professional marginality and the individualization of organisational work}

These secondary activities thus divert the actor's art away from its classical technical aims-artistic representation. Similarly, such activities are far removed from actors' traditional collaborators and recruiters. These professional spaces can therefore certainly constitute places of sociability and support for artists in difficulty (Menger 2011 [2005]), but the professional marginality of such spaces means that effective meetings between the two are rare. Extras for television or cinema, for example, are at the centre of some of the support networks of the actors interviewed. However, they are classed in this context as "living scenery" (Sigalo Santos 2014), and do not gain access to the important intermediaries by this route. Similarly, you can "meet wonderful people" doing corporate roleplay work, according to some of the interviewees-but these will be other actors, rather than the directors who are likely to recruit them.

27 Significantly, amongst the self-taught actors interviewed here, the desire to be educated (specifically due to professional placements) corresponds just as much to their wish to acquire traditional acting skills as to the search for a relatively stable professional situation in the theatrical field. 
rencontres "selon les termes de certains enquêtés. Mais elles ont lieu entre acteurs, jamais avec des metteurs en scène susceptibles de les recruter.

Cette caractéristique négative recèle une dimension supplémentaire. Dès lors que les comédiens n'évoluent plus dans un contexte de création artistique susceptible de les valoriser auprès des recruteurs, le travail invisible qu'ils déclarent devoir fournir pour " se vendre » augmente fortement. Alors que les emplois théâtraux les plus légitimes assurent une visibilité qui construit, à la faveur du travail artistique lui-même, réputation et entregent professionnels, l'effort de veille et d'information sur les activités à pourvoir est d'autant moins efficace que ces acteurs évoluent dans des espaces non légitimes, en dehors des réseaux les plus intégrateurs. Faute d'identifier tout à fait ce mécanisme, les comédiens interrogés le retournent fréquemment contre euxmêmes, l'assimilant à une défaillance personnelle :

« J'ai jamais été très douée, à courir les premières, à courir les mondanités [...] J'ai toujours préféré le travail à ça. Et mine de rien c'est devenu important de ce côté là. II faut savoir paraître et se vendre et aller chercher... enfin, c'est les deux quoi. Moi c'est vrai que je sais travailler. Je suis d'accord pour qu'on vienne voir mon travail, c'est làdessus que je me défends. Mais après, j'ai peut-être plus de mal à être... Ou c'est peut-être quelque chose que j'ai pas assez fait, et du coup je me sens un peu isolée. » (Céline B., 29 ans, comédienne, formée à l'École nationale supérieure d'art dramatique de Montpellier, est exclue depuis un an et demi de l'indemnisation chômage en janvier 2012 , vit à Paris.)
This negative characteristic harbours an extra dimension. Since the actors are no longer developing within a context of artistic creation likely to promote them in the eyes of recruiters, the "invisible work" that they say they must do in order to "sell themselves" fiercely increases. While the more legitimate theatre jobs guarantee a visibility which builds actors' reputations and professional interpersonal skills, to the benefit of artistic work itself, the effort of keeping an eye out for other opportunities is even less effective for actors evolving in illegitimate spaces, outside of integrationist networks. The interviewed actors have difficulty in identifying this mechanism and often feel a sense of personal failure as a result.

"I've never been very good at running after premières, socializing, you know [...] l've always preferred working to all that. Regardless, this side of things has become important. You have to know how to get noticed and sell yourself, to go for it [...] well, it's both sides in the end. Personally, I know how to work. I'm fine with people coming to see my work, that's when I can stand up for myself. But then, it's a little harder for me to [...] or, maybe it's something I haven't done enough, so I feel a little isolated." (Céline B., 29 years old, lives in Paris, trained at the École nationale supérieure d'art dramatique in Montpellier. Excluded from unemployment benefits for one and a half years from January 2012). 
En réalité, « savoir paraître et se vendre », pour reprendre les mots de cette comédienne, est une compétence « paraprofessionnelle » (Pilmis 2007a) qu'un travailleur doit d'autant plus mobiliser qu'il évolue sur un marché du travail flexible et qu'il n'a pas (ou pas encore) noué de relations suffisamment durables avec des employeurs réguliers. Le travail de placement et de mise à disposition de soi, mais aussi de coordination et d'arbitrage entre les offres d'emploi potentielles, s'apparente ainsi à une réponse individuelle à l'externalisation de la gestion des compétences et du risque d'obsolescence de la main d'œuvre. Or, comme l'a analysé Pierre-Michel Menger, ce sont avant tout les réseaux professionnels qui, au niveau collectif, « facilitent les recrutements par cooptation et l'identification des compétences sur la base des réputations individuelles » (Menger 2011 : 46-47). Ils émergent comme des « éléments de stabilité qui sont la nécessaire contrepartie de [cette] recherche permanente de flexibilité et de réduction des frais fixes », et constituent ainsi des « mécanismes de structuration des relations interindividuelles qui opèrent à la croisée de ce que serait un mode de relations ponctuelles, sans mémoire et sans cesse changeantes, et de ce que peut être l'organisation au sein d'une entreprise ou d'un groupe professionnel formellement clos sur lui-même » (Menger 2011 : 46-47). Les inégalités entre ceux qui sont au cœur des relations d'interconnaissance les plus denses et ceux qui en sont exclus correspondent précisément à cette inégalité d'accès à ce travail d'organisation des réseaux. Ceux qui sont situés sur les segments professionnels les plus dépréciés doivent par conséquent le compenser individuellement, avec d'autant plus de difficulté qu'ils manquent de ressources pour

le faire.
Knowing "how to get noticed and sell yourself," as this actress puts it, is a "para-professional" skill (Pilmis 2007a) that an employee must be able to use-especially within a flexible employment market-when he or she has not (or not yet) made enough professional connections to regular employers. Placing oneself and making oneself available, while also coordinating and sifting through potential job opportunities, thus resembles an individual response to the outsourcing of management skills and the risk of workforce obsolescence. Yet, as analysed by Pierre-Michel Menger, it is above all professional networks that, at the collective level, "facilitate recruitment by co-option and the identification of skills based on individual reputations" (Menger 2011: 46-47). They emerge as the "stable elements that are the necessary counterpart to [this] permanent search for flexibility and fixed-costs reduction." They thus constitute "structuring mechanisms of interpersonal relations which take place at the crossroads of a type of short-term relationship-quickly forgotten and constantly changing - and the potential organization within a company or a professional group that is formally closed on itself" (Menger 2011: 46-47). The inequalities present between those who find themselves at the centre of the most tightly knit interpersonal acquaintances, and those who are excluded from such relations correspond precisely to the unequal access to this organizational resource provided by networks. Those who are situated within the most undervalued professional sections must therefore make up for it individually, and do so with difficulty, since they lack resources. 
C'est donc doublement que les activités « hors métier » sont peu valorisantes : conçues comme peu épanouissantes, elles ne permettent pas non plus aux comédiens impliqués d'évoluer au-delà d'un espace de travail limité et peu légitime. Le sentiment de dispersion identitaire qu'elles occasionnent est ainsi redoublé par un déficit de confirmation professionnelle. II n'est donc pas rare que les comédiens interrogés déclarent avoir abandonné de tels palliatifs ou évoquent leur projet de le faire, quitte à renoncer au bénéfice de l'assurance chômage.

\section{Conclusion}

La qualification par l'accès au « statut » d'« intermittent » - i.e. l'indemnisation chômage - dissimule dans les faits une disparité de niveaux d'intégration professionnelle. Dans cette perspective, la perte de ces droits est l'aboutissement d'une dégradation des conditions d'emploi et de travail expérimentée bien en amont. Centrer l'observation sur les processus de désaffiliation professionnelle invite à mettre au jour, du fait de l'hétérogénéité des trajectoires prises en compte, les principes contradictoires de stabilisation dans l'activité et de disqualification à l'œuvre sur le marché du travail de comédien. Sur ce marché qui est de toute évidence flexible et peu régulé, les emplois les mieux financés, et en définitive, les plus respectueux des normes salariales, y sont précisément rares et convoités. Dans cette perspective, l'emploi théâtral public assure non seulement une fréquence d'activité et de cotisation, mais aussi des conditions de travail favorables. C'est le fait de pouvoir y accéder ou non qui explique, à ce titre, les inégalités de maintien des comédiens
The jobs that are indirectly related to the profession are therefore doubly unrewarding: since they are designed to be unfulfilling, they do not allow the actors concerned to evolve beyond a limited and barely legitimate working space. The sense of identity dispersion they cause is therefore intensified by a lack of professional affirmation in the workspace. It is not uncommon that some interviewed actors claim to have abandoned such temporary solutions, or evoke their intention to do so, even if this means giving up the right to unemployment compensation.

\section{Conclusion}

Accessing the intermittent performer status -in other words, unemployment compensation-in fact hides a disparity between levels of professional integration among actors. From this perspective, the loss of these rights is the culmination of a degradation in employment and working conditions experienced a long time before. Focusing on the process of professional disaffiliation-thanks to the heterogeneity of the trajectories considered here-leads us to reveal the conflicting principles of stabilization and disqualification at work in the labour market of the acting profession. In this evidently flexible and under-regulated market, publiclyfunded positions and, ultimately, those that best respect salary standard, have therefore become rare and coveted. In this light, public theatre jobs ensure not only a regular number of jobs and insurance contributions, but also favourable working conditions. It is the fact of access-or lack of-to such jobs, which thus explains the inequalities between levels of support for actors in the profession. Yet, the acting trade 
dans le métier. Or, ce métier doit s'entendre de deux façons complémentaires : d'une part, comme une communauté de travail où mobiliser ses savoir-faire et être reconnu ; d'autre part, comme un contenu technique attribué au travail, réalisable dans des conditions matérielles spécifiques. Dans cette optique, l'étude de la situation des comédiens exclus de l'indemnisation chômage met en évidence leur adhésion très limitée aux formes altérées de leur activité que supposent les conditions ultra-flexibles de l'emploi. Ils restent ainsi polarisés vers des emplois et une pratique professionnelle auxquels ils n'ont pourtant été, au mieux, que très imparfaitement introduits. Il est donc possible que les conditions de régulation du marché du travail réservent l'art du comédien, tel qu'appris dans les écoles, seulement à une minorité de salariés intégrés et qualifiés. II apparaît cependant que la conversion des autres aux positions professionnelles peu valorisées s'effectue rarement avec leur assentiment.

Serge Katz Université de Picardie Jules Verne/CNRS UMR 7319, CURAPP-ESS https:// www.u-picardie.fr/curapp/

\section{Références bibliographiques}

BECKER Howard S. (1985). Outsiders. Études de sociologie de la déviance. Traduction française par Jean-Pierre Briand et Jean-Michel Chapoulie. Paris, Métailié.

BeCKeR Howard S. (2009). « Préface ». In Bureau Marie-Christine, Perrenoud Marc, Shapiro Roberta (dir.), L’Artiste pluriel. Démultiplier l'activité pour vivre de son art. Villeneuve d'Ascq, Presses Universitaires du Septentrion : 13-16. must be understood from two complementary perspectives: on the one hand, as a work community in which actors can use their skills and gain recognition; and on the other hand, as the technical skillset of the work, which can be realized within specific material conditions. Studying the situation of actors excluded from unemployment compensation thus illustrates their very limited access to the changing forms of the job which stem from extremely flexible working conditions. They thus remain constrained to a form of employment and professional practice they have scarcely been prepared for. It is therefore possible that the conditions of regulation of the labour market mean that the art of acting, as learned in schools, is the reserve of a minority of qualified, socially and professionally well-connected employees. It would appear, however, that the conversion of the rest to positions of little recognition rarely occurs with their consent.

Serge Katz Université de Picardie Jules Verne/CNRS UMR 7319, CURAPP-ESS https:/ www.u-picardie.fr/curapp/

\section{References}

BECKER Howard S. (1963). Outsiders: Studies in the Sociology of Deviance. New York, The Free Press of Glencoe.

Becker Howard S. (2009). "Préface." In Bureau Marie-Christine, PerRenoud Marc, Shapiro Roberta (eds.), L'Artiste pluriel. Démultiplier l'activité pour vivre de son art. Villeneuve d'Ascq, Presses Universitaires du Septentrion: 13-16. 
Bense Ferreira-Alves Celia (2006). Précarité en échange. Enquête sur l'implication au travail. Montreuil, Éditions Aux lieux d'être.

Bourdieu Pierre (1971). "Le marché des biens symboliques 》. L'Année sociologique, 22 : 49-126.

BUREAU Marie-Christine \& SHAPIRO Roberta (2009). « Et à part ça, vous faites quoi ? Introduction ». In Bureau Marie-Christine, PeRRENoud Marc, SHAPIRO Roberta (dir.), L'Artiste pluriel. Démultiplier l'activité pour vivre de son art. Villeneuve d'Ascq, Presses Universitaires du Septentrion : 17-34.

CARDon Vincent (2011). Une vie à l'affiche. Sociologie du vieillissement en emploi des artistes interprètes (thèse de doctorat en sociologie). Paris, EHESS.

CARDON Vincent (2016). «Produire "'évidence". Le travail d'appariement et de recrutement dans le monde du cinéma ». Sociologie du travail, 58(2) : 160-180.

CARDON Vincent \& PILMIS Olivier (2013). « Des projets à la carrière. Les artistes interprètes et leurs anticipations des contreparties du travail, une perspective biographique ». Sociétés contemporaines, 91:43-65.

Centre de sociologie du travall et des arTs (EHESS-CNRS) (2005). Enquête sur le devenir professionnel des artistes issus des écoles supérieures d'art dramatique signataires de la plateforme de l'enseignement supérieur pour la formation du comédien. Paris, Jeune théâtre national.

Champy Florent (2009). La Sociologie des professions. Paris, Presses Universitaires de France.

CORSANI Antonella \& LAZZARATO Maurizio (2008). Intermittents et précaires. Paris, Éditions Amsterdam.
Bense FerreiRa-Alves Celia (2006). Précarité en échange. Enquête sur l'implication au travail. Montreuil, Éditions Aux lieux d'être.

BOURDIEU Pierre (1985). "The Market of Symbolic Goods." English translation by Rupert Swyer. Poetics, 14(1-2): 13-44.

Bureau Marie-Christine \& Shapiro Roberta (2009). "Et à part ça, vous faites quoi? Introduction." In Bureau Marie-Christine, PerRenoud Marc, SHAPIRO Roberta (eds.), L'Artiste pluriel. Démultiplier l'activité pour vivre de son art. Villeneuve d'Ascq, Presses Universitaires du Septentrion: 1734.

CARDon Vincent (2011). Une vie à l'affiche. Sociologie du vieillissement en emploi des artistes interprètes ( $\mathrm{PhD}$ dissertation, Sociology). Paris, EHESS.

CARDON Vincent (2016). "Produire 'l'évidence'." Le travail d'appariement et de recrutement dans le monde du cinéma". Sociologie du travail, $58(2)$ 160-180.

CARDon Vincent \& PILmIs Olivier (2013). "Des projets à la carrière. Les artistes interprètes et leurs anticipations des contreparties du travail, une perspective biographique." Sociétés contemporaines, 91: 43-65.

Centre de sociologie du travall et des aRTS (EHESS-CNRS) (2005). Enquête sur le devenir professionnel des artistes issus des écoles supérieures d'art dramatique signataires de la plateforme de l'enseignement supérieur pour la formation du comédien. Paris, Jeune théâtre national.

Champy Florent (2009). La Sociologie des professions. Paris, Presses Universitaires de France.

CoRsani Antonella \& LAZZARATO Maurizio (2008). Intermittents et précaires. Paris, Éditions Amsterdam. 
DemaZlèRE Didier \& GADÉA Charles (dir.) (2009). Sociologie des groupes professionnels. Acquis récents et nouveaux défis. Paris, La Découverte. FREIDSON Eliot (1986). « Les professions artistiques comme défi à l'analyse sociologique ». Revue française de sociologie, 27(3) : 431-443.

Friot Bernard (1998). Puissances du salariat. Emploi et protection sociale à la française. Paris, La Dispute.

GILLE Jean-Patrick (2013). Les Conditions d'emploi dans les métiers artistiques : rapport d'information déposé en application de l'article 145 du Règlement par la Mission d'Information commune en conclusion des travaux de la mission sur les conditions d'emploi dans les métiers artistiques. Paris, Assemblée nationale.

GRÉGOIRE Mathieu (2013). Les Intermittents du spectacle. Enjeux d'un siècle de luttes (de 1919 à nos jours). Paris, La Dispute.

JEANPIERRE Laurent (2012). « De l'origine des inégalités dans les arts 》. Revue française de sociologie, 53(1) : 95-115.

Katz Serge (2005). Les Écoles du comédien face au "métier". Recrutements professionnels, classements scolaires, techniques du corps. Une comparaison franco-allemande (thèse de doctorat en sociologie). Paris, EHESS.

KATZ Serge (2006). "Quand savoir faire c'est savoir être. L'élève comédien à l'épreuve de la perception professionnelle de son corps ». In MAUGER Gérard (dir.), L'Accès à la vie d'artiste. Sélection et consécration artistiques. Bellecombe-en-Bauges, Le Croquant : 49-70.

KATZ Serge (2008). " Jouer sur les mots. Langage et apprentissage théâtral en France et en Allemagne ». Ethnologie française, 38(1) : 39-48.

KATZ Serge (2015). Comédiens par intermittence. Le métier à l'épreuve de la disqualification professionnelle. Paris, Presses du Châtelet.
Demazlère Didier \& GadÉA Charles (eds.) (2009). Sociologie des groupes professionnels. Acquis récents et nouveaux défis. Paris, La Découverte. FREIDSON Eliot (1986). "Les professions artistiques comme défi à l'analyse sociologique." Revue française de sociologie, 27(3): 431-443.

FRIOT Bernard (1998). Puissances du salariat. Emploi et protection sociale à la française. Paris, La Dispute.

GILle Jean-Patrick (2013). Les Conditions d'emploi dans les métiers artistiques: rapport d'information déposé en application de l'article 145 du Règlement par la Mission d'Information commune en conclusion des travaux de la mission sur les conditions d'emploi dans les métiers artistiques. Paris, Assemblée nationale.

GRÉGOIRE Mathieu (2013). Les Intermittents du spectacle. Enjeux d'un siècle de luttes (de 1919 à nos jours). Paris, La Dispute.

JeANPIERRE Laurent (2012). "De l'origine des inégalités dans les arts." Revue française de sociologie, 53(1): 95-115.

KatZ Serge (2005). Les Écoles du comédien face au "métier." Recrutements professionnels, classements scolaires, techniques du corps. Une comparaison franco-allemande ( $\mathrm{PhD}$ dissertation, Sociology). Paris, EHESS.

KaTZ Serge (2006). "Quand savoir faire c'est savoir être. L'élève comédien à l'épreuve de la perception professionnelle de son corps." In MAUGER Gérard (ed.), L'Accès à la vie d'artiste. Sélection et consécration artistiques. Bellecombe-en Bauges, Le Croquant: 49-70.

KATZ Serge (2008). "Jouer sur les mots. Langage et apprentissage théâtral en France et en Allemagne." Ethnologie française, 38(1): 39-48.

KaTZ Serge (2015). Comédiens par intermittence. Le métier à l'épreuve de la disqualification professionnelle. Paris, Presses du Châtelet. 
LAILLIER Joël (2011). « La dynamique de la vocation : les évolutions de la rationalisation de l'engagement au travail des danseurs de ballet ». Sociologie du travail, 53(4) : 493-514.

LAMBERT Benoît (1998). " Le metteur en scène et la peau de ses comédiens ». Sociétés et représentations, $6: 465-483$.

LANGEARD Chloé (2013). Les Intermittents en scène. Travail, action collective et engagement individuel. Rennes, Presses Universitaires de Rennes.

MAUGER Gérard (2006). « Les arts du spectacle. Introduction ». In MAUGER Gérard (dir.), L'Accès à la vie d'artiste. Bellecombe-en-Bauges, Le Croquant : 5-11.

Menger Pierre-Michel (1997). La Profession de comédien. Formations, activités et carrières dans la démultiplication de soi. Paris, La Documentation Française.

MengeR Pierre-Michel (2011) [2005]. Les Intermittents du spectacle. Sociologie du travail flexible. Paris, Éditions EHESS.

MouLIN Raymonde (1983). « De l'artisan au professionnel : l'artiste ». Sociologie du travail, (25)4 : 388-403.

Paradeise Catherine (1998). Les Comédiens. Profession et marchés du travail. Paris, Presses Universitaires de France.

Perrenoud Marc (2007). Les Musicos. Enquête sur des musiciens ordinaires. Paris, La Découverte.

Perrenoud Marc (2013). «Prendre au sérieux l'artisanat musical. Utilité, reproductibilité, prestation de service ». In PERRENOUd Marc (dir.), Les Mondes pluriels de Howard S. Becker. Travail sociologique et sociologie du travail. Paris, La Découverte : 85-98.
LAILLIER Joël (2011). "La dynamique de la vocation: les évolutions de la rationalisation de l'engagement au travail des danseurs de ballet." Sociologie du travail, 53(4): 493-514.

LAMBERT Benoît (1998). "Le metteur en scène et la peau de ses comédiens." Sociétés et représentations, 6: 465-483.

LANGEARD Chloé (2013). Les Intermittents en scène. Travail, action collective et engagement individuel. Rennes, Presses Universitaires de Rennes.

MAUger Gérard (2006). "Les arts du spectacle. Introduction." In Mauger Gérard (ed.), L'Accès à la vie d'artiste. Bellecombe-en-Bauges, Le Croquant: 5-11.

Menger Pierre-Michel (1997). La Profession de comédien. Formations, activités et carrières dans la démultiplication de soi. Paris, La Documentation française.

MengeR Pierre-Michel (2011) [2005]. Les Intermittents du spectacle. Sociologie du travail flexible. Paris, Éditions EHESS.

MoULIN Raymonde (1983). "De l'artisan au professionnel: l'artiste." Sociologie du travail, 25(4): 388-403.

PARAdeISe Catherine (1998). Les Comédiens. Profession et marchés du travail. Paris, Presses Universitaires de France.

Perrenoud Marc (2007). Les Musicos. Enquête sur des musiciens ordinaires. Paris, La Découverte.

Perrenoud Marc (2013). "Prendre au sérieux l'artisanat musical. Utilité, reproductibilité, prestation de service." In PERRENOUd Marc (ed.), Les Mondes pluriels de Howard S. Becker. Travail sociologique et sociologie du travail. Paris, La Découverte: 85-98. 
PILMIs Olivier (2007a). « Compétences professionnelles et compétences para-professionnelles sur le marché du travail : les journalistes pigistes et le "placement de sujet" ». Formation et Emploi, 99 : 75-87.

PILMIS Olivier (2007b). " Des "employeurs multiples" au "noyau dur" d'employeurs : les relations de travail des comédiens intermittents et la concurrence sur le marché ». Sociologie du travail, 49(3) : 297-315.

PILMIS Olivier (2012). « Le professionnalisme comme engagement sur le marché du travail. Le bénévolat des comédiens intermittents ». In BERCOT Régine, DivaY Sophie, GadÉA Charles (dir.), Les Groupes professionnels en tension. Frontières, tournants, régulations. Toulouse, Octarès : 43-55.

PIOTET Françoise (2002). « Introduction ». In PIOTET Françoise (dir.), La Révolution des métiers. Paris, Presses Universitaires de France : 1-19.

Proust Serge (2001). « Une nouvelle figure de l'artiste : le metteur en scène de théâtre ». Sociologie du Travail, 43(4) : 471-489.

PRoust Serge (2003). « La communauté théâtrale : entreprises théâtrales et idéal de la troupe ». Revue française de sociologie, 44(1) : 93-113.

Proust Serge (2009). « La pluriactivité dans une économie administrée : le théâtre public ». In Bureau Marie-Christine, Perrenoud Marc, Shapiro Roberta (dir.), L'Artiste pluriel. Démultiplier l'activité pour vivre de son art. Villeneuve d'Ascq, Presses Universitaires du Septentrion : 95-107.

RANNOU Janine \& ROHARIK Ionela (2006). Les Danseurs, un métier d'engagement. Paris, La Documentation française.

Rolle Valérie \& MoEschlen Olivier (2014). De l'école à la scène. Entrer dans le métier de comédien-ne. Lausanne, Éditions Antipodes.

Rose José (2012). Qu'est-ce que le travail non qualifié ?. Paris, La Dispute.
PILMIS Olivier (2007a). "Compétences professionnelles et compétences para-professionnelles sur le marché du travail: les journalistes pigistes et le 'placement de sujet'." Formation et Emploi, 99: 75-87.

PILmIs Olivier (2007b). 'Des 'employeurs multiples' au 'noyau dur' d'employeurs: les relations de travail des comédiens intermittents et la concurrence sur le marché." Sociologie du travail, 49(3): 297-315.

PILMIS Olivier (2012). "Le professionnalisme comme engagement sur le marché du travail. Le bénévolat des comédiens intermittents." In BERCOT Régine, DIVAY Sophie, GADÉA Charles (eds.), Les Groupes professionnels en tension. Frontières, tournants, régulations. Toulouse, Octarès: 43-55.

PIOTET Françoise (2002). "Introduction." In PIOtet Françoise (ed.), La Révolution des métiers. Paris, Presses Universitaires de France: 1-19.

Proust Serge (2001). "Une nouvelle figure de l'artiste: le metteur en scène de théâtre." Sociologie du Travail, 43(4): 471-489.

Proust Serge (2003). "La communauté théâtrale: entreprises théâtrales et idéal de la troupe." Revue française de sociologie, 44(1): 93-113.

Proust Serge (2009). "La pluriactivité dans une économie administrée: le théâtre public." In Bureau Marie-Christine, Perrenoud Marc, Shapiro Roberta (eds.), L'Artiste pluriel. Démultiplier l'activité pour vivre de son art. Villeneuve d'Ascq, Presses Universitaires du Septentrion: 95-107.

RANNOU Janine \& ROHARIK Ionela (2006). Les Danseurs, un métier d'engagement. Paris, La Documentation française.

RoLLe Valérie \& MoESCHLER Olivier (2014). De l'école à la scène. Entrer dans le métier de comédien-ne. Lausanne, Éditions Antipodes.

Rose José (2012). Qu'est-ce que le travail non qualifié?. Paris, La Dispute. 
SAPIRO Gisèle (2007). « La vocation artistique entre don et don de soi ». Actes de la recherche en sciences sociales, $168: 4-11$.

SCHotté Manuel (2013). « Le don, le génie et le talent. Critique de l'approche de Pierre-Michel Menger ». Genèses, 93 : 144-164.

SIGALO SANTOS Luc (2014). « Le recrutement des figurants de l'audiovisuel. L'ANPE Spectacle, un intermédiaire public sur le marché des images ». Revue française de socio-économie, 14(2) : 15-39.

Sinigaglia Jérémy (2012). Artistes, intermittents, précaires en lutte. Retour sur une mobilisation paradoxale. Nancy, Presses Universitaires de Nancy.

SINIGAGLIA Jérémy (2013). " Le bonheur comme rétribution du travail artistique. De l'injonction à l'incorporation d'une norme ». Sociétés contemporaines, $91: 17-42$

SORIGNET Pierre-Emmanuel (2014). « Norme professionnelle et légitimité de la violence. Le cas des danseurs ». Déviance et Société, 38(2) : 227250.

THIBAULT Adrien (2015). «Être ou ne pas être : la genèse de la consécration théâtrale ou la constitution primitive du talent ». Sociologie et sociétés, 47(2) : 87-111.

URRUtIAGUer Daniel \& Henry Philippe, avec la collaboration de DuCHÊnE Cyril (2011). Territoires et ressources des compagnies en France. Paris, DEPS, Ministère de la Culture.

Verdalle Laure (DE) (2006). Le Théâtre en transition. De la RDA aux nouveaux Länder. Paris, Éditions de la MSH.

WeBER Florence \& LAMY Yvon (1999). « Amateurs et professionnels ». Genèses, $36: 2-5$.
SAPIRO Gisèle (2007). "La vocation artistique entre don et don de soi." Actes de la recherche en sciences sociales, 168: 4-11.

Schotté Manuel (2013). "Le don, le génie et le talent. Critique de l'approche de Pierre-Michel Menger." Genèses, 93: 144-164.

SigALO SANTOS LuC (2014). "Le recrutement des figurants de l'audiovisuel. L'ANPE Spectacle, un intermédiaire public sur le marché des images." Revue française de socio-économie, 14(2): 15-39.

Sinigaglia Jérémy (2012). Artistes, intermittents, précaires en lutte. Retour sur une mobilisation paradoxale. Nancy, Presses Universitaires de Nancy.

SINIGAGLIA Jérémy (2013). "Le bonheur comme rétribution du travail artistique. De l'injonction à l'incorporation d'une norme." Sociétés contemporaines, 91: 17-42.

SORIGNET Pierre-Emmanuel (2014). "Norme professionnelle et légitimité de la violence. Le cas des danseurs." Déviance et Société, 38(2): 227250.

THIBAULT Adrien (2015). "Être ou ne pas être: la genèse de la consécration théâtrale ou la constitution primitive du talent." Sociologie et sociétés, 47(2): 87-111.

Urrutiaguer Daniel \& Henry Philippe, with Duchêne Cyril (2011). Territoires et ressources des compagnies en France. Paris, DEPS, Ministère de la Culture.

Verdalle Laure (DE) (2006). Le Théâtre en transition. De la RDA aux nouveaux Länder. Paris, Éditions de la MSH.

WeBER Florence \& LAMY Yvon (1999). "Amateurs et professionnels." Genèses, 36: 2-5. 